\title{
As Origens da Condenação do Processo Civil Romano*
}

\author{
Guilherme Carneiro Monteiro Nitschke
}

1 Introdução. 2 Antecedentes arcaicos. 2.1 o votum. 2.2 Os legados per damnationem e sinendi modo 2,30 nexum 2.4 Damnatio como vínculo e execução per manus iniectionem. 3 A condena ção pecuniária das fómulas. 3.1 A condemnatio enquanto elemento da fórmula e o oficio do pretor $32 \mathrm{~A}$ condemnatio enquanto espécie de sentença. 4 Da damnatio à condemnatio. 5 Condemnatio e litis contestatio. 6 Conclusẫo. Referências.

Resumo: Este trabalho visa a demonstrar que a condenação do processo formular romano se originou de uma paulatina evoluçăo da damnatio, uma das antigas modalidades obrigacionais que tinham a submissäo como elemento caracterizador e a garantia como centro do vínculo Substituída a idéia de obrigação como garantia pela idéla de obrigaçăo como vínculo ideal, e considerando a natureza instrumental de que o processo se reveste, a damnatio foi intemalizada ao sentenciamento engendrou o que se conhece por condemnatio, a submeter o devedor näo mais aos castigos sacrais, mas ao próprio populus Romanus. O texto, ademais, divide-se no exame dos aspectos externos e intemos da sentença de condenaçăo, ressaltando, neste úlimo caso, suas relaçôes com a obligatio, com a actio e com a litis contestatio, e sempre tendo por prisma o oficio que pretor e juiz assurniam no processo daqueles tempos.

Palavras chave: Direito Romano. Processo Civil Condenaçăo. Obrigação. Açấ. Litis Contestatio.

Abstract: This paper aims at demonstrating that condemnation of the Roman formular procedure originated from a regular evolution of damnatio, one of the old obligational modalities, which had submission as a characterizing element and warrant as the core of the bond Once the idea of obligation as warrant" was substituted for "obligation as ideal bond", and considering the instrumental nature of the procedure, damnatio was intemalized to sentencing. originating what is known as condemnatio, submitting the debtor no longer to sacral punishments, but to the populus Romanus itself. The text, in addition, is divided into analyzing the intemal and extemal aspects of the condemnation verdict, highlighting, in the latter case, its relationships to obligatio, to actio

\footnotetext{
- Pela confíança, pela ajuda, pelo incentivo e pelo exemplo indelevel de professor, advogado e pessoa, não há como não dedicar este trabalho inteiramente ao Prof. Luís Renato Ferreira da Silva.

${ }^{1}$ Mestrando em Direito pela UFRGS.
} 
and to litis contestatio, always considening the role that praetor and judge took on in the legal proceeding at that time.

Reywords: Roman law. Civil Procedure. Condemnation Obligation. Action. Litis Contestatio.

"These rudimentary ideas are to the jurist what the primary crusts of the earth are to the geologist. They contain, potentially, all the forms in which law has subsequently exhibited itself". Henry Sumner Maine*

\section{Introdução}

O conhecimento histórico faz-se pela segurança dós instrumentos que o tempo preservou. Extirpada a possibilidade de acesso direto aos fatos passados, esșa cognição se processa por meio de vestígios, assim imputando certo grau de incerteza à almejada correspondếncia entre o resultado da pesquisa histórica e o fato outrora ocorrido. Como bem aponta o fundador da Escola dos Annales, "nenhum egiptólogo viu Ramsés; nenhum especialista das guerras napoleônicas ouviu o canhão de Austerlitz. Das eras que nos precederam, só poderíamos falar segundo testemunhas. Estamos, a esse respeito, na situação do investigador que se esforça para reconstruir um crime ao qual não assistiu; do físico, que, retido no quarto pela gripe, só conhece os resultados de suas experiências graças aos relatórios de um funcionário de laboratório". ${ }^{2}$ Por isso, o passado é, por definição, um dado imodificável; seu conhecimento, porém, é coisa que progride, e que incessantemente se transforma e se aperfeiçoa, ${ }^{3}$ pois fitados estão os olhos do pesquisador na busca pelo real - ainda que seja o real de outros tempos - e embebidos pela pertinácia de avistarem a verdade.

\footnotetext{
"MAINE, Henry Sumner. Ancient law Londres: Aldine Press -.. Letchworth - Herts (Everyman's Library), 1965, p. 2.

${ }^{2}$ BLOCH, Marc. Apologie pour l'histoire ou métier dhistorien (Cahiers des Annales). 2. ed. Paris: Amand Colin, 1952, p. 17.

${ }^{3}$ Idem, p. 22.
} 
E que outros são os instrumentos para o conhecimento do direito pretérito senẫo as próprias palavras, senão a linguagem? "Amálgamas de pedaços dos espíritos" que perduram "indiferentes ao passar das geraçōes" - poetizou Pontes de Miranda ${ }^{4}$-, as palavras não passam de signos convencionais que representam imediatamente as concepçōes do intelecto e mediatamente - mas não necessariamente - a realidade. A linguagem, por ser convencional (lapidada pelo ser humano), é modo de expressão social e manifestação eminente da tradição, ${ }^{5}$ e tanto por isso espelha e aponta para a realidade jurídica de épocas passadas. É, destarte, legítimo instrumento do historiador do direito, pois realiza a própria essência da tradição: o repasse, a transmissâo, a traditio (de trado, trans + do, entregar) dos fatos de outros tempos.

Considerando que ao passado jurídico só se tem acesso por mediação de pálavras, é possivel desdobrar duas conclusões: que as palavras enquanto instrumentos de investigação histórica indicam à realidade de outras épocas, mas que, por também fazerem parte da cultura humana e por isso sofrerem iguais modificaçöes por ação do tempo, a segurança de sua correspondência (identificação entre descrição por palavras e realidade) só brota se forem encaradas dentro da sistemática de dados já conhecidos. ${ }^{6}$ A visão geral da realidade

\footnotetext{
TONTES DE MIRANDA, Francisco Cavalcanti Garra, măo e dedo. Campinas: Bookseller, $2002, \mathrm{p}, 10$.

5 SAUSSURE, Ferdinand de Cours de linguistique generale. 2 ed Paris Payot 8 Cle, 1922 p. 100-101. Como bem aponta Juan Cruz Cruz, tradición es la línea de la transmisión de los caracteres adquiridos por libertad, es la continuidad del proceso operativo especificamente humano en virtud de la cual se lega al futuro algo que pervive, una yez desapareciendo quien lo creo, el pasado es asi un legado, del que el hombre puede disponer (..) La tradición desde el lado del emisor es entrega; desde el lado del receptor es acogimiento. La manera más alta en que se actualiza es en la educación y su manifestación más inmediata es el lenguaje (CRUZ, Juan Cruz La historia como tradición. Anuario filosófico. Navarra EUNSA, v $13, n$. 1980 , p. 75 e 95 , respectivamente)

As leis de modificação da linguagem não são muito diversas das apresentadas pelas demais criaçoes da arte humana. Por ação do tempo, conjuntos gramaticais somem e aparecem, e outros têm seu uso modificado. For isso que indica Giacomo Devoto ser impossivel estudar certa palavra e perquinr a que realidade ela aponta apartando-a de sua dimensão histónco cultural (DEVOTO, Gacomo. Ricostruzione e storia di lingue. In: Scriti Minori. Firenze: Felice le Monnier, 1967, vi 1, p. 35).
} 
jurídica, social, econômica etc. da época investigada, assim, é vetor indispensável ao desvelar seguro de quais circunstâncias uma determinada palavra era representante. Nas trilhas desse método, o investigador há de ter uma dupla capacidade: capacidade histórica para colher com acerto tudo quanto há de característico no direito de cada época, e capacidade sistemática para considerar cada dado em íntima relação e em ação recíproca com o conjunto.?

A exposição dessas considerações preliminares se justifica quando a aproximação à temática deste trabalho é maior: tratará ele de perquirir as origens da condenação no processo civil romano, e para isso será indispensável viajar ao período arcaico de Roma e observar em quaís círcunstâncias era utilizado o vocábulo que a etimologia indica como ascendente direto da condemnatio - qual seja, a damnatio. Por serem escassas as fontes jurídicas desses tempos, apenas a observação sístemática da palavra (inserta no conjunto jurídico, social e econômico de entẫo) é capaz de portar maior segurança ao investigador, de modo a fazê-lo defrontar com razoável probabilidade o conceito e a realidade aos quais se referia a palavra damnatio.

Nem se diga que o método perde justificativa quando - estudo passa a abordar períodos mais adiantados da história jurídica de Roma. A maior abundância de fontes e de escritos sobre o processo formular nảo retira da investigação do passado sua natureza cambiante (no sentido de evoluir a cada novà descoberta na trilha da evolução à verdade), mormente quando se tem em mente as recentes descobertas que a arqueologia patrocinou para o direito. ${ }^{8} \mathrm{O}$ desenvolvimento

\footnotetext{
${ }^{7}$ SAVIGNY, Friedrich Karl von De la vocación de nuestro siglo para la legislación y la ciencia del derecho (trad. Adolfo G Posada). Buenos Aires. Atalaya, 1946, p. 80 . 8 Alem da pesquisa tecnológica nos papiros de Oxyrhynchus (antiga cidade egípcia em que fol descoberto em 1896 um enorme amontoado de papiros milenares, contendo desde anotaçöes do dia-a-dia dos antigos até obras literánas perdidas), basta recordar a rica lex Imitana, que em 1981 foi encontrada na localidade de Saucejo, na Espanha (foram retiradas do local sels tebuas de bronze em que a lei está gravada), e que modificou sobremaneira o entendimento que se tinha acerca de alguns elementos do processo formular romano (ěpoca de Domiciano). $\mathrm{Cf}$.
} 
das pesquisas, aliás, tem revelado que muitas idéias lapidadas pelos romanistas dos séculos passados merecem ser atualizadas e desbastadas de sua bagagem ideológica, circunstância que reforça ainda mais a necessidade de retomarem-se velhas discussões e abordarem-se caracteres do processo romano que já pareciam descansar irretorquíveis.

Assim sendo, para que seja possível elaborar um esboço de proposta sobre as origens da condenação no processo civil romano, os seguintes degraus terăo de ser galgados: em primeiro lugar, analisar-se-á a que realidade correspondia à palavra damnatio no tempo arcaico, avaliando-se, por outro lado, de que forma se operava a transição "conhecimentoexecução" nesses mesmos idos; em segundo lugar, investigarse-á a configuração da condemnatio formular, pulando-se temporariamente do período arcaico para o período clássico, e com isso traçando um comparativo de evolução entre damnatio e condemnatio; enfím, o estudo culminará na avaliação dos caracteres obrigacionais da condenaçâo romana, a demonstrar que, de alguma maneira, seu uso determinava a submissão do réu ao cumprimento da sentença.

\section{Antecedentes Arcaicos}

Por meio da etimologia, o mergulho no arcaísmo é meramente superficial: revela uma série de possiveis ascendentes do vocábulo damnatio sem, porém, considerar o plexo que deve haver entre palavra e contexto cultural. Não indica com firmeza a que dado da realidade romana o termo fazia referência, e por isso serve de modesto acessónio ao aprofundamento da dimensão cultural da linguagem. Uma pesquisa comprometida nâo pode se deter em meros comparatismos etimológicos: ${ }^{9}$

GONZALES, Julian; CRAWFORD, Michael. H. The Lex Irnitand: a new copy of the Flavian Municipal Law. The Joumal of Roman Studies; 1986; v. 76, pp. 147-243.

- Apenas em tom exemplificativo, refira-se aqui que as pesquisas etimológicas relacionam damnatio com o indo-uropeu (dÂ, dap, "dop-nom de "ligar", "vincular". Cf. CRIFO, Gullano. Danno (storia), In: Enciclopedia Giurdica Italiona. [s.l.]; A. Guffrè, 1962, p. 167. GIOFFREDI, Carlo. Dirito e processo nelle antiche forme

Cadernos do PPG em Direito UFRGS, Porto Alegre, v. 6, n. 7 e 8, p. 223-291, 2007. 
No caso da condemnatio, em especial, por seu ascendente estar tão soterrado pelo tempo, mister se faz partir da palavra e verificar em que variados contextos ela tinha uso nas épocas mais distantes do direito de Roma, durante o denominado "período arcaico". "Sabe-se ser ela o resultado da junção de dois termos arcaicos: cum e damnatio. $O$ primeiro deles (uma preposição) tem significado óbvio: "com", "em companhia de", "por meio de". "O segundo, porém (um substantivo), demanda investigação hístórico-sistemática mais apurada, já que seu aparecimento é variado e envolto nas brumas de um passado longínquo. Dentre algumas ocorrências, é possivel indicar o uso de damnatio como vinculado a quatro institutos jurídicos da época: o votum, os legados per damnationem e sinendi modo, e o nexum. A análise compartimentada de cada um deles fará brotar, ao final, o significado de damnatio que aqui se busca.

\subsection{0 votum}

Relacionada ao votum, a palavra damnatio é mencionada por diversos autores romanos. Comélio Nepo (De viris illustribus, XXII, 5), Virglio (Ecloga, V, 79-80), Tito-Lívio (Ab urbe condita, V, 21 e 25) e Macróbio (Satumalia, III, 2) são alguns dos exemplos mais marcantes. A chave está em descobrir o que se entendia por votum, e de plano salta aos olhos o

\footnotetext{
romane. Roma: Apollinaris, 1955, p. $168-169$, nota n ${ }^{\circ} 20$ ), com o sânscrito (dam-yâmit, de "domar". Cf BOPP, Franz Grammaire comparée des langues indo-européennes (trad. Michel Breal); 2. ed. Paris; Imprimerie Imperiale, 1866, t. 1, p. 254), com o etrusco (-mno, -mina Cf. FRNOUT, A Les eléments étrusques du vocabulaire latine. Bulletin de la société de linguistique de Paris. Paris: Librarie Ancienne Honore

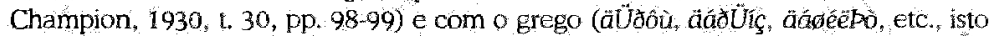
é, "divisão", "despesa" e "magnânimo". Cf. ERNOUT, A.; MEILLET, A. Dictionnaire etymologique de la langue latine: histoire des mots. 3. ed. Paris; C. Kincksieck, 1951 , p. 293).

10 Periodo que vai desde os primórdios de Roma (apesar de juridicamente iniciar com a redação das XII Tábuas, no século $\mathrm{V}$ a.C.) até o fim da Segunda Guerra Púnica, no fechamento do século lll a.C.

in São algumas das traduçóes indicadas por SARAJVA. F. R dos Santos. Noússimo dicionário latino-portugués etimológico, prosódico, histótico, geográfico, mitológico, biográfico etc. 11. ed. Rio de Janeiro-Belo Horizonte: Gamier, 2000, p. 324.
} 
acentuado caráter religioso que o instituto possuía. O próprio Cícero, na obra De legibus (II, 47), refere à sua feição sacral quando o inclui no rol exemplificativo de institutos jurídicos que partilhavam de relações com a religião: de sacris credo, de votis, de feris et de sepulchris. Em específico, a participação do votum na religião romana se operava por meio da nuncupatio, que nada mais era senầo o proferimento rigoroso e solene, diante do público ou ao menos de algumas testemunhas, de certas palavras (certa verba) indicadas pelos pontífices e dirigidas ao deus Júpiter, capazes de gerar obrigaçōes para quem as pronunciasse. ${ }^{12}$

Com isso, fica claro que pelo votum se implorava a algama deidade que realizasse certa benesse, prometendo-se a ela, em contrapartida, certa retribuição caso o pedido fosse atendido (como a construção de um templo ou o sacrificio de animais). Virgílio narra a história de um sujeito que venceu um páreo de barcos apenas porque proferira vota aos deuses (Eneida, V, 230-240). Noutra passagem do texto, o mesmo autor fala sobre as oraçōes de Ascânio a Júpiter antes que lançasse uma flecha na cabeça de Rêmulo, prometendo-lhe "bezerro cândido de fronte dourada" caso acertasse o alvo (IX, 625). Marcos Cato, enfim, em texto que trata do mundo campestre dos romanos, indica todas as formalidades que deviam ser atendidas para que se formulasse um votum em favor da saúde do gado (De agri cultura, 83). A partir desses exemplos, é tranqüilo concluir-se pela natureza do votum: uma declaração unilateral de vontade, ${ }^{13}$ uma promessa feita a uma divindade, vinculante segundo o ius sacrum. ${ }^{14}$

\footnotetext{
in Sobre isso, cf. Julio César, De bello civile, $\mathrm{I}$, 6. Suetónio, Divus Augustus, 97 . Cf. tambem NOAILLES, Pierre. Du droit sacré au droit civil. Paris: Recueil Sirey, 1949. p. 302. Nuncupare vem de nomen e capere, isto e, "nome" e "apanhar", etimologia que reforça a idéla de que nuncupató era exprimir à viva voz as palavras devidas, oferecidas pelos pontfices.

13 WORMS, René De lá uolonté unilatérale considérée comme source d'obligations en droit romain et en drot français. Paris: A Girard, 1891, P. 82. Cf. também D. 50.12.2. ${ }^{14}$ PUGLIESE, Giovanni: Istituzioni di diritto romano. 3. ed. Torino. G. Giappichelli, 1991, p. 595 .
} 
Via de regra, os vota eram cumpridos por temor à ira dos deuses e à fúria de seus seguidores. Dizia-se votum solvere o implemento da promessa que tinha sido feita. ${ }^{15}$ Mas antes desse cumprimento, o promitente podia se encontrar numa de duas situaçóes: ou voti reus, ou voti damnatus.

É de Virgilio (Eneida, V, 235) uma passagem interessante sobre o ponto: constitutam ante aras voti reus ("em vossos altares, obrigo-me por esta promessa"), trecho que posteriormente foi comentado por Macróbio (Saturnalia, III, 2), ut reus qui suscepto voto se numinibus obligat (de modo que diz-se reus o que em dirigindo a promessa se obriga"). Essas fontes tratam de momentos em que se tinha um voti reus, isto é, alguém que havia se obrigado pelo votum depois de ter proferido palavras solenes (nuncupatio). Voti reus era, assim, o sujeito que prometera determinada realização caso atendido seu pedido.

Por outro lado, quando a condição se implementava (id est quando o desejo do proferente se realizava) e o promitente se negava a cumprir sua promessa, dizia-se que ele havia se tornado voti damnatus (o contrário, portanto, de votum solvere). Nesse sentido, vejam-se as observaçöes de Macróbio (Saturnalia, III, 2): damnatus autem qui promissa vota non solvit ("damnatus, porém, é o que nâo cumpriu os votos prometidos"). A expressão também é utilizada noutras fontes. Cornélio Nepo (De viris illustribus, XXI, 5), por exemplo, assim escreveu: dixit nunc demum se voti esse damnatum: namque hoc a diis immortalibus semper precatum, ut talem libertatem restitueret Syracusanis, in qua civis, de quo vellet, impune dicere (“disse em tal momento estar damnatus a uma promessa: já que por sempre pedir isto aos deuses imortais, para que fosse restituída a liberdade dos Siracusanos, na qual fosse lícito a qualquer um falar do que quisesse sem ser castigado").

\footnotetext{
is Votum solvere era "s acquiter d'un voeu" (ERNOUT, A. MEILLET, A., Dictionnaire étymologique de la langue latine, cilt. p. 634). Solvo originaria, posteriormente, as palavras absolvo, absolutus, absolutio, e significava "romper", "quebrantar", "satisfazer", "livrar-se de", "saldar", "liquidar", elc (SARANA, F R dos Santos; Nouíssimo dicionário latino-português etimológico, prosödico, histórico, geogrâfico, mitológico, biognáfico etc., cit, p. I.III).
} 
Já de Virgílio (Ecloga, 79-80) pode ser citado o seguinte: Ut Baccho Cererique, tibi sic vota quotannis agricolae facient: damnabis tu quoque votis ("Como, para Baco e Ceres, todos os agricultores fazem para ti as promessas: damnabis tu também a elas"). E de Tito-Livio (Ab urbe condita, V, 25): Camillus identidem omnibus locis contionabahur: haud mirum id quidem esse, furere civitatem quae damnata voti omnium rerum potiorem curam quam religione se exsolvendi habeat ("nos discursos que repetia continuamente em todos os lugares, Camilo dizia que não era então tão estranho se abandonasse a tais excessos uma cidade que, em sendo damnata ao cumprimento de um voto, fazia de tudo para se liberar do vínculo religioso").

Os trechos revelam o sentido em que damnatio e suas derivaçóes eram utilizadas pelos romanos quando se referiam ao votum: damnatum, damnabis e damnata indicavam a situação de um indivíduo que descumprira uma promessa era, portanto, $\sigma$ antípoda de votum solvere, de cumprir o voto - e que, assim, estava submetido à sua realização sob pena de sofrer sançōes religiosas. No plano do fas, parece que o promitente ficava submetido à ira divina (danaçâo); no plano do ius sacrum, provavelmente os veneradores da deidade desrespeitada pudessem perseguir em juízo o cumprimento do prometido ${ }^{16}$ Damnatio enquanto relacionada ao votum, destarte, espelhava vinculação por não cumprimento de promessa feita e, assim, submissâo aos castigos divinos e religio$\operatorname{sos}^{17}$

\subsection{Os legados per damnationem e sinendi modo}

Outra aparição arcaica da palavra damnatio se dá quando relacionada aos legados per damnationem e sinendi modo. $\mathrm{O}$

\footnotetext{
is FIRPO, Giulio. Votum. In: Nouíssimo Digesto Italiano. Torino: Unione Tipografico Editrice Torinese, [s.d.], iv. 20, p. 1.060 .

${ }^{17}$ É importante notar desde já a dicotomia havida entre solvere e damnatio: votum solvere (solvere que mais tarde originaria absolvere, absolver) era "desligar-se da promessa" "e "ficar imune das penas religosas", ao passo que uoti damnatus (expressäo com o termo damnatio, que depois engendraria condemnatio, condenar) era "submeter-se às penas religiosas por ter descumprido uma promessa".
} 
legado, no direito romano, resultava da faculdade que possuía o paterfamilias de destinar suas coisas mortis causa a quem the aprouvesse, materializado por meio de testamento ou de codicilo confirmado, imposto aos herdeiros em favor de um terceiro (legatário). Segundo registros dos Tituli ex Gorpore Ulpiani (XXIV, 2) e das Institutiones de Gaio (II, 192), havia quatro modalidades de legado nos tempos mais antigos: per damnationem, sinendi modo, per vindicationem e per praeceptionem; os dois primeiros gerando efeitos pessoais, os dois últimos gerando efeitos reais. ${ }^{18}$ Tendente à unificação, o Senatus Consultum Neronianum (64 d.C.) fez com que a interpretação de legados impróprios (aqueles que não cumpriam com os requisitos de nenhuma das modalidades) convergisse para um só: na dúvida, deviam ser vistos como se per damnationem fossem (Gaio, Institutiones, II, 197-198; 212-218; 220-222; Tituli ex Corpore Ulpiani, XXIV; 11 ; Fragmenta Vaticana, 85); e o período pós-clássico, por fim, observou derrocar a divisão entre legados per damnationem e legados per vindicationem, unificando estes àqueles.

Pouco a pouco, o legado per damnationem foi expandindo seus lindes e acabou por englobar todos os outros, dada a carapaça obrigacional da qual se revestia. Caracterizava-se por impor ao herdeiro algum dever em favor de um terceiro, seja de dar ou de fazer. Legado "que gerava em favor do legatário um simples direito de crédito contra o herdeiro", ${ }^{19} \mathrm{e}$, por conseguinte, que fazia nascer no próprio herdeiro determinada dívida. Sua principal característica decorria de seu objeto: uma espécie de obrigação entre legatário e herdeiro. Tanto por isso diferenciava-se do legado per vindicationem, utilizado para repasse direto de coisas e, portanto, com efeitos tipicamente reais, prescindindo inclusive de qualquer intervenção do herdeiro.

\footnotetext{
18 Álvaro D'Ors acrescentou outras duas modalidades às já conhecidas o legado optio servi (legado de opção) e o legado partitio (legado de partiçâo), sem, porém, indicar em que fontes se baseava (D ORS, Álvaro. Derecho privado romano. 9. ed. Navarra: EUNSA, 1997; p. 373-375).

BIONDI, Biondo. Corso di dirtio romano, Dirito ereditario. Milano: A. Gilufiè, 1934 , p. 241.
} 
Outro legado revestido de caráter obrigacional era o sinendi modo, tanto que abarcado pelo per damnationem mesmo antes do anno Domini. Ele, porém, impunha ao herdeiro uma obrigação de "não impedir" (sinere); fixava um dever de permitir que o legatánio tomasse o que o de cujus lhe havia deixado. A simples diferença do per damnationem repousava na espécie de obrigação gerada por um e por outro, conforme assinala Biondo Biondi: num, uma obrigação positiva; noutro, uma obrigação negativa. ${ }^{20}$

Esse caráter obrigacional que a ambos era intrínseco tinha como marca a presença da cláusula damnas esto. Senão, basta que se cotejem as fórmulas indicadas por Gaio (Institutiones, II) quando faz referência às quatro modalidades de legado: 201. Per damnationem hoc modus legamus: HERES MEVS STICHVM SERVVM MEVM DARE DAMNAS ESTO. 209. Sinendi modo ita legamus: HERES MVS DAMNAS ESTO SINERE LVCIVM TITIVM HOMINEM STICHVM SVMERE SIBIQVE HABERE 193. Per vindicationem hoc modo legamus: TITIO verbi gratia HOMINEM STICHVM DO LEGO. 216. Per praeceptionem hoc modo legamus: LVCIVS TITIVS HOMINEM STICHVM PRACIPITO (também nos Tituli ex Corpore Ulpiani, $\mathrm{XXIV}, 4$ e 5 , podem ser achadas passagens similares). De todas essas frases (repetidas pelos testadores em verdadeiro nuncupare), apenas nas duas primeiras - as referentes aos legados per damnationem e sinendi modo - consta a declaração damnas esto, não por acaso naqueles ditos "obrigacionais".

A tradução literal dessa expressão, mantido por ora o damnas em sua configuraçâo latina, fica: "esteja damnas a dar" (dare damnas esto, referente ao legado per damnationem) e "esteja damnas a não impedir" (damnas esto sinere, referente ao legado sinendi modo). Não é dificil concluir que o vocábulo damnas era usado para deduzir a vontade do testador em termos formais, qual seja, a de que seu próprio herdeiro ficasse comprometido a seguir determinada conduta, beneficiando

\footnotetext{
${ }^{20}$ BIONDİ, Biondo. Legato (dirito romano) Novissimo Digesto Italiano. Torino: Unione Tipografico-Editrice Torinese, [s.d.], v. 9, p. 559-560.
} 
terceiro. Damnas, assim, representava de certa maneira a submissão do herdeiro à vontade do de cujus, e configura o indício mais agudo da obrigacionalidade dos legados per damnationem e sinendi modo. Tanto que as fórmulas citadas podem muito bem ser traduzidas por "esteja vinculado ou submetido a dar" e "esteja vinculado ou submetido a não impedir"; tanto que "legado per damnationem" nada mais é do que "legado por vinculação", ou "legado por submissáo": ${ }^{21}$

\subsection{0 nexum}

Foi o romanista alemão Philipp Eduard Huschke, através da obra "Ueber das Recht des nexum und das altrömischen Schuldrecht” (Leipzig, 1846), quem encetou as célebres discussões sobre o nexum, um misterioso instituto do direito romano. Tão controvertida quanto sua própria natureza era a presença da palavra damnatio como a ele vinculada. Huschke, por exemplo, acabou deduzindo o uso de damnatio a partir do próprio efeito executório que parecia brotar do nexum, sendo supostamente pronunciada pelo credor contra o devedor durante o cerimonial do cobre e da balança (per aes et libram). ${ }^{22} \mathrm{O}$ romanista partiu do pressuposto de que o ato do cobre e da balança gerava uma dualidade de efeitos: um real, implicando a transferência por mancipação de um bem; e outro obrigacional, através do qual o contrato era criado pelo nexum, isto é, pelo engajamento pessoal dos serviços do contratante. Este último seria efetivado depois de pronunciada (via nuncupatio) uma damnatio, a dar azo imediato a uma execuçăo (manus iniectio pro iudicato).

É interessante verificar que os anos conscguintes reservaram uma diversidade de desdobramentos da teoria de

\footnotetext{
${ }^{21}$ A idéla de vínculo e de obrigação que brota da expressão dare damnas é tăo fone que alguns autores chegaram às ralas de considerar dita cláusula como predecessor da dare oportet dos tempos clássicos. Cf. THOMAS. Paul. La nature de la damnatio. Revue historique de droit français et étranger. París: Recueil Sirey, série 4 , ano 10,1931, p. 232.

22 SENN, Félix. Nexurn: contract de prêt du trés ancien droit romain. Nouvelle revue historique du droit français et étranger. Pans: Recueil Sirey, ano 29, 1.905, p. 52.
}

Cademos do PPG em Direito UFRGS, Porto Alegre, v. 6, n. 7 e 8, p. 223-291, 2007. 
Huschke. $\mathrm{O}$ alemão Ludwig Mitteis, através de trabalho publicado na "Zeitschrift der Savigny - Stiftung für Rechtgeschichte, Romanistische Abteilung" (1901), foi o primeiro a combatêla. Afirmando não haver qualquer fonte a atestar a presença da damnatio como vinculada ao nexum, e também por isso descartando a possível manus iniectio pro iudicato, Mitteis procurou diferenciar nexum de nexi: enquanto aquele seria contrato de empréstimo per aes et libram, implementável forçadamente por uma legis actio sacramento in personam, os nexi seriam os aprisionados por quaisquer dívidas impagas que houvessem decorrido do mútuo (forma de auto-mancipação), perseguidos através de uma rei vindicatio. Em sua compreensão, não havia espaço para uma damnatio e menos ainda para a possibilidade de execução direta.

Os autores sucessivos a Huschke e Mitteis a um ou a outro se filiaram - com exceção de Otto Lenel, que acabou negando a própria existência do nexum. ${ }^{23}$ Sem prejuízo de que uma ou que outra teoria esteja correta, o importante aqui é verificar que feição assumia a damnatio se vinculada ao nexum, e ter-se por pressuposto, evidentemente, o acerto dos estudos de Huschke e seus seguidores.

Conforme já adiantado, para essa corrente, o nexum era um contrato de empréstimo, celebrado per aes et libram, com a pronúncia solene (nuncupatio) de uma damnatio, em que o devedor submetia sua força de trabalho como garantia da dívida. Isso é exatamente o que parece espelhar um dos fragmentos da Lei das XII Tábuas (VI, 1): cum nexum faciet mancipiumque, uti lingua nuncupassit, ita ius esto ("quando se realize um nexum ou uma mancipação, o que se declare verbalmente de forma solene seja direito"). O nexum, portanto, era negócio formal, cumprido mediante a pesagem do metal e na presença de cinco testemunhas, tal como na

\footnotetext{
${ }_{23}$ Para anâlise das três correntes derivadas de Huschke, Mitteis elenel, bem como de seus seguidores, veja-se NOAllLS, Pierre. Fas et ius: études de droit romain. Paris: Les Belles Lettres, 1948 , p. 49.57.
} 
mancipatio. ${ }^{24}$ Fazia com que o mutuante adquirisse um poder sobre a pessoa de quem recebesse a utilidade econômica, caso a contraprestação não fosse efetuada: frustrada a fiducia que dava impulso ao negócio, o devedor respondia diretamente com seu corpo. ${ }^{25}$

É de Pierre Noailles a preciosa indicação de que era o labor do mutuário, e não sua liberdade, que ficava submetido ao poder do mutuante caso o empréstimo não fosse recompensado. ${ }^{26}$ Chamado, assim, de liber homo bona fide serviens (expressão colhida da lex Cincia, conforme revelam os Fragmenta Vaticana, 307), o nexus tinha sua força laborativa escravizada sem que sua pessoa se revestisse dessa mesma condição. Até que a dívida estivesse quitada, ficava ele sob o senhorio de seu credor. ${ }^{27} \mathrm{O}$ mutuante podia apanhar o devedor e levá-lo para exercer atividades laborativas até que seu crédito fosse satisfeito; podia exercer diretamente, como está subentendido, uma manus iniectio diferenciada.

A corrente de romanistas por fim indica a damnatio como responsável por atar o devedor ao credor e à realizaçâo do labor empenhado. $\mathrm{O}$ vocábulo pronunciado, portanto, representava a vinculação e a submissäo do mutuário caso näo pagasse o que tomara por empréstimo. Por isso a

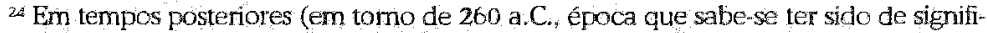
cativo crescimento da cunhagem de moedas de prata, com o exaurimento das fontes de cobre), a pesagem do metal se transformou en mero ato simbólico as partes se detinham a tocar a balança com pedaços de cobre (JORS, Paul, KUNKEL; Wolfgang. Derecho privado romano (trad L Pietro Castro). Barcelona: Labor, 1965, p. 131).

${ }^{25}$ IMBERT, Jean Fides et nexum. Studi in onore di Vicenzo Arangio-Ruiz Napoli Jovene, [s.d] w 1, p. 358 .

${ }^{26}$ NOAILLES, Pierre, Fas et ius: études de droit romain, cit., p. 114.

${ }^{27}$ A condicâo de nexus parece ter surgido como soluça a paupérrima realidade que assolava algumas classes da sociedade tomana da época', que, năo possuindo bens às garantias de seus débitós, tinham de submeter suas próprias pessoas como penhor (GIOFFREDI, Carlo. Nexum Novissimo Digesto Italiano torino Unione Tirográfico-Editrice Torinese, [s.d.], v. 11, p. 271). De outro lado, como credores, os patrícios usavam o empréstimo de dinheiro e cereais como meio de acumular homens e mão-deobra para seus latifúndios, sistemática peculiar à Antigüidade que contribuia para $o$ inintertupto domínio da classe patricia e faziam-na perpetuar como senhora de Roma (WEBER Max. Historia económica general (trad Manuel Sanchez Sarta): México: Fondo de Cultura Económica, 1997, p. 62-63).
} 
importância de sua presença na face obrigacional do nexum: pela força da nuncupatio, a damnatio representava a garantia de que o mutuante teria seu património recomposto, já que submetia de per si o devedor ao poder de seu credor e ao cumprimento de seus trabalhos até que a dívida estivesse quitada.

2.4 Damnatio como vínculo e execução per manus iniectionem

Não escapa do leitor qual uso era dado, nos tempos arcaicos, ao vocábulo damnatio: ele exprimia espécie de "vínculo" e "submissão", derivados de uma declaração solene de palavras certas (nuncupatio), indicando a instituição de uma garantia e com força suficiente para submeter o indivíduo, em caso de descumprimento, a um procedimento de execução imediato; ela representava a constituição de uma garantia dirigida à asseguraçắo de que certos deveres seriam cumpridos de maneira voluntária ou, na pior das hipóteses, por meio de coação. É isso que se viu nos três exemplos recém-trazidos: no votum, a presença da damnatio espelhava vinculação por não cumprimento de promessa feita e, assim, submissão a castigos divinos e relígiosos; nos legados per damnationem e sinendi modo, a cláusula damnas esto impunha ao herdeiro um dever de fazer ou de năo fazer em prol de um terceiro; e no nexum, a damnatio submetia o devedor ao poder de seu credor e ao cumprimento de certos trabalhos até que o débito restasse pago. Nos três, a damnatio operaya por meio de uma nuncupatio, e, também nos três, o inadimplemento dos deveres acarretava uma espécie de execução sem procedimentos de conhecimento que the fossem anteriores. Por isso, a palavra parece ser mais bem traduzida por espécie de "vinculação", por "submissão" ${ }^{28}$

\footnotetext{
z Prova complementar do sentido de damnatio como especie de vínculó e revelada por certa passagem das XII Tábuas (VIII, 16) SI ADORAT FURTO, QUOD NEC MANIFESTUM ERIT DUPLIONE DAMNUM DECIDITO. No trecho, damnum decidere pode ser traduzido por "decidir o vinculo", a exprimir a funçăo do juiz quando examinava alguma relaçăo conflituosa posta sob seus olhos. Expressao, por sinal, que não pode andar desacompanhada de seu antônimo da epoca: a palavra.
} 
Ainda outro aspecto pode ser destacado. É que a damnatio, nesses primeiros tempos de Roma, não era vocábulo que se relacionasse díretamente com o processo civil. A diferença da condemnatio das épocas posteriores, ela - a damnatio - pertencia exclusivamente ao âmbito material do direito, e não consistia em instrumental de magistrados ou de juízes como na posteridade se tornaria. A única relação que desde já pode ser apontada com o processo é sua capacidade de oportunizar execuçōes caso não observados os deveres cujo cumprimento era por ela garantido. E é justamente dessa aptidão que tratar-se-á a partir de agora.

A manus iniectio - execução do período arcaico - foi definida da seguinte maneira pelo jurista Gaio (Institutiones, IV, 21): Qui agebat, sic dicebat: QUOD TU MIHI IUDICATUS SIVE DAMNATUS ES SESTERTIUM X MILIA, QUANDOC NON SOLVISTI, OB EAM REM EGO TIBI SESTERTIUM $X$ MILIUM IUDICATI MANUM INICIO; et simul aliquam parte corporis elus prehendebat ("quem agia, assim dizia: "já que tu és iudicatus ou damnatus a dez mil sestércios e não pagaste, agarro-te por isso a título de julgado pelos dez mil sestércios"; e em seguida prendia uma parte de seu corpo"). Ou um iudicium, ou uma damnatio: a execução dependia da presença de um ou de outro para ser encetada, já que ambos transmitiam a segurança de que um dever fora descumprido e portanto carecia de salvaguarda. Há que se analisar, assim, no que consistia uma manus iniectio ex iudicium e uma manús iniectio ex damnatio, pois indispensável para diferenciar-se a causa de cada uma das espécies - não obstante a similitude de seu procedimento, como se verá no final do ponto.

A manus iniectio ex iudicium é a mais conhecida modalidade de execução, já que desdobrada a partir de um pronunciamento judicial que nos primốrdios assumia feição bastante sacral. Nos dizeres de Scialoja, quem tihha declaração da

solvere, que, desde então, já significava "desobrigar se", "desvincular se" Nầ é por acaso que o processo civil dos séculos posteriores acabou tendo de um lado condemnare (cum + damnare) e de outro absolvere $(a b+$ solvere). 
estirpe ao seu favor tinha aptidão à execução sobre a pessoa do devedor ${ }^{29}$ e tanto por isso a causa de uma manus iniectio ex iudicium, nesses tempos mais arcaicos, era a decisão de um julgador (inspirado por deuses) que dizia se certa conduta estava ou não de acordo com o direito (normas religiosas) reconhecido da época. ${ }^{30} \mathrm{O}$ juízo desta primeira época, portanto, era oblíquo e indireto, pois tinha por precípua função detectar a conformidade de alegações e fatos e daí, em nome dos deuses desrespeitados, punir aqueles que tivessem incorrido em perjúrio.

O iudicium do período arcaico, porém, não apresentava feições perenes e duradouras. Não se pode dar a ele uma definição única, separando-a em absoluto do que depois o período formular ofereceria. Pelo contrário, o iudicium - como todo o direito romano da época - participava de uma sociedade que se abria a outras culturas e aos poucos se laicizava, trocando o revestimento sacral de suas instituiçōes por um de cunho mais racional e adequado à cosmopolitização que as conquistas bélicas ensejavam. Tanto foi assim que aos poucos

29 SCIALOJA, Vittoro. Procedimiento ciul romano: ejercicio y defensa de los derechos (trad. Santiago Santis Melendo e Marino Ayerra Redin). Buenos Aires: EsJE, 1954 p. 149 .

3o Importante aludir que o iudicum era alcancado por meio da legis actio sacramento, açäo tão arcaica que parece ter derivado da prática jurídica grega dos tempos heróicos (SCIALOJA, Vittorio, Procedimiento ciul romano: ejencicio y defensa de los derechos, cit, p. i40). O sacramentum como procedimento não tinha por escopo o adimplemento de obrigaçoes năo cumpridas, mas a puniçăo daqueles que houvessem prestado juramento falso perante as divindades. Ainda que a declaraçáo do que era o justo concreto fosse decorrencia do juizo sacral, a finalidade deste era puramente ordalica; a decisão do sacramentum representava nada mais do que a vontade divina (LEVY-BRUHL, Henri Le sacramentum in personam. In: Studi in onore di Vicenzo Arangio-Ruiz. Napoli: Jovene, [s.d.], v 2, p. 17). Caso restasse provada a falsidade de seu juramento, o sujeito, nos ptimeiros tempos, tomava-se homo sacer, e podia inclusive ser morto em sacrificio (sacer facio) aos deuses para que a fúna destes fosse apaziguada (MEIRA Silvió A. B. O homo sacer no antigo direito romano. Romanites: Revista de Cultura Romana (íngud, instituiçoes e direito). Rio de Janeiro: Romanitas, 1959 , ano 2, v. 2, p. 9496). A gararitia pelo próprio corpo foi substituída ainda na idade régia pelo depósito de animais: aqueles que haviam sido dados pelo sucumbente eram consagrados e sacrificados às divindades: Em tempos mais adiantados, o sacramentum tomou-se pecuniánio e servia de soma expiatốria, para, jă no período helênico, transformap-se em mera poena que revertia ao erário em puniçấo à sucumbência. 
o processo civil da época passou a ser o nascedouro de açốcs da lei cada vez mais voltadas à realização prática do justo (a legis actio per iudicis arbitrive postulationem e a legis actio per condictionem constituem exemplos típicos do que ora se diz), desenraizado do assoreamento religioso que lhe travava um resultado mais efetivo e humano. ${ }^{31}$.

$\dot{E}$ a partir desses dados, casados com um notável desenvolvimento do cobre e depois da moeda como instrumentos do comércio, que a manus iniectio passou a se desdobrar apenas se o iudicium fosse expressado com referência a quantias pecuniárias. ${ }^{32}$ Caso não o fosse, fazia-se necessário seguir um arbitrium liti aestimandae - procedimento autônomo, consistente na liquidação da decisão -, e só entâo os triginta dies para o pagamento voluntário passavam a correr, sob pena de dar-se início à execução (Lei das XII Tábuas, III, 1). ${ }^{33}$

\footnotetext{
${ }^{31}$ Para llustrar, recorde-se que nesta época Roma começava sua dilataçấ bélica, guerreando contra os montanheses, a partir de 430 a.C., e contra a Etrúra, de 387 a 347 a.C. (PIGANIOL, André. Histoire de Rome. Paris: Presses Universitairés de France, 1939, p. 51-67). Também nestes idos, Cneus Flduius - secretárior de um jurisconsul to - publicou o calendáno ponafical e um livro com as fómulas processuais que até entã̃o eram detidas aperias pelos colégios pontificais, abrindo aos profanos o estudo e o desenvolvimento do direito (D. 1.2.2.7). Esses e outros acontecimentos contri-buían para que uma idéa de Populus Romanus brotasse com cada vez mais força e, de centa forma, en substituiçầ à religião que antes tudo impreg. nava.

${ }^{32}$ É o que confirma a Lei das XII Tábuas, III, 1, na senda da legislação que à época instituia o sistema capitalista da Antigüidade romana (lex Aetemia Tarpeia, de 454 a.C. lex Menenia Sestia, de 452 a.C. lex Papiria Julia, de 430 a.C.), dando ensejo à execuçăo por barras de metal (aes), depols por lingotes (barras de metal fundido grafados como termo ROMANOM), e depols por moedas (MOMMSEN, Theodore. Histoire de la monnaie romaine (trad. Duc de Blacas). Paris: [s.n.], [s.d.], t. 1, p. 173-178). Isso năo afasta, entretanto, que, em tempos anteriores (quando inexistia a prâtica do cobre e da moeda), a execução fosse feita pela própria colsa (ín ipsam rem), como menciona Gaio em suas Institutiones (IV, 48), a mitigar inclusive uma suposta divisão original de açôes in personam e açôes in rem (ROMANO, Angela. Condanna "in ipsam rem" condanna pecuniaria nella stona del processo romano. Labeo rasegna di dirtto romano. [s.1.]: [s.n.]. 1989, n. 28, p. 145).

${ }^{33}$ Diga-se, aliass, que o mês que antecedia a execuçà só valia para quem estivesse sujeito a determinada obrigaçào por conta de um iudicium ou de uma confissắo (conforme noticia a Lei das XII Tábuas, 11I, 1-2), e näo por uma damnató, quie podia dar azo à direta manus iniectio a qualquer tempo.
} 
Visto, portanto, que a manus iniectio ex iudicium tinha por causa uma decisão judicial com feição pecuniária e descumprida pelo devedor, há que se passar agora à segunda espécie de execução que Gaio menciona em suas Institutiones (IV, 21): a manus iniectio ex damnatio. Considerando que o significado de damnatio já foi explicitado em linhas anteriores, o importante agora é observar de que maneira seus caracteres interagiam com a execução arcaica a ponto de configurarem mais um requisito à instauração daquela ação da lẹi. $E$ aqui é indispensável adiantar-se uma diferenciaçăo que nos parágrafos mais abaixo ficará clara: a damnatio não é o equivalente arcaico de obligatio, e por isso mesmo nâo representa a existência de uma obrigação incontroversa, mas de uma garantia ao cumprimento de promessas proferidas.

Para entender-se bem a execução arcaica, deve-se saber que a noção de obrigação não tinha sido desenvolvida na época da damnatio. ${ }^{34}$ Os romanos trabalhavam com promessas e com a garantia de que elas seriam cumpridas, e não com obligationes. Aqui entra o essencial papel da damnatio: ela não tornava obrigação alguma incontroversa, pois sequer a noção de "obrigaçâo" fazia-se presente na prática mais antiga a oportunizar adjetivaçấo da estirpe. $\mathrm{O}$ que a damnatio representava - e isso tern tudo a ver com a ponte que a conecta à execução - era uma submissão do devedor aos deuses e ao credor e uma garantia de que as promessas feitas de maneira solene (nuncupatio) seriam cumpridas. Mais do que isso. A necessidade em ter-se por incontroverso o descumprimento da obrigação só adveio - como se verá mais adiante - num período em que (i) a noçâo de obligatio já se encontrava lapidada, (ii) a declaração do juiz já substituía a certeza religiosa fornecida pela nuncupatio e (iii) a execução

\footnotetext{
34 Fritz Schulz adverte que mesmo o surgmento do vocábulo obligatio é terdio, concomitante à lapidaçâo de sua noçäo como vinculum iuris. Como as palavras evoluem atadas à contingencia que representam; 0 antecedente obligare aparecia com o significado de "atar": (SCHULZ, Fritz. Derecho romano clásico (trad. José Santa Cruz Teijeiro). Barcelona: Bosch, 1960, p. 435).
} 
não era mais realizada privadamente pelo credor, mas sob a coordenaçăo total do magistrado.

Pela damnatio, a submissão era essencialmente religiosa, e por isso o descumprimento do prometido ensejava de per si a execução do credor, mormente por já haver a submissão pelas promessas proferidas. ${ }^{35}$ Aliás, é bem isso que se viu quando analisado o aparecimento da palavra damnatio, sempre atrelada a atos praticados solenemente (com a pronúncia de fórmulas certas: nuncupatio) e diante de testemunhas (testis). A presença de terceiras pessoas observando a prática da solenidade tinha por exato fito dar publicidade (perante os deuses, o credor e a comunidade) às promessas feitas e à garantia instituída. A violação das promessas, portanto, era agressäo à própria sociedade romana e desrespeito às divindades citadinas. ${ }^{35}$ Por isso se pode dizer que a damnatio configurava, de certo modo, "causa substancial notória" à manus iniectio, ainda que o descumprimento de ditas promessas fosse a verdadeira causa eficiente da execução.

Tanto que, num primeiro momento histórico, a sanção que derivava da damnatio, motivada pelo descumprimento das promessas proferidas, era apenas religiosa: quem não cumpria os deveres se tomava herege (impius) e sofria diversas restriçōes em sua colocação social ${ }^{37}$ - até, pelo menos, que um sacrificio expiatorio the retirasse a pecha de blasfemo.

\footnotetext{
3s Já em tempos posteriores, a religiao cedeu espaço pata noçốes secularizadas; sem que os institutos juridicos perdessem, porém, o arraigamento cultural que thes era intrínseco. Especifcamente no caso da damnatio, a submissäo que antigamente era religiosa parece ter sido substituída por uma submissão ao populus Romanus, ao estoço de Estado que se fomara com a evolução da Republica, e por isso essa submissão nấo poderia mais ser o ponto de partida, mas o ponto de chegada de um processo de conhecimento judicial que culminasse na instituiça dessa submissão, numa sentenca cum domnatio, depois de detectada gue uma obrigação (aqui sim no sentido de uinculum iurs) havia sido descumprida.

36. JHERING, Rudolf won LEsprit du droit momain (trad. O de Meulenaere). 3. ed Panis: [s.n] ], 1886-1888, t. 1, p. $15 \mathrm{I}$

37. Era, por exemplo, afastado das cerimônias religiosas citadinas (WORMS, Rerié, De la volonté unilatérale considérée comme source dobligations en droit romain et en droit français, cit, p. 71 ).
} 
Foi a paulatina laicização dos institutos que portou a necessidade de uma sanção não sacral, seja porque o papel hiperbólico da religião encolhia, seja porque, com bastante probabilidade, o próprio prejudicado não se contentava mais com meras penalizações beatas; e daí, então, foram abertas as portas para que a manus iniectio se instalasse como conseqüência ao damnatus.

Mas disso não resulta que a manus intectio ex damnatio possa ser vista como espécie de manus iniectio pro iudicato (isto é, uma manus iniectio que se equiparava àquela cuja causa era o iudicium), conforme compreenderam alguns conhecidos estudiosos do processo civil romano ${ }^{38}$ Não levaram em conta a contraposição feita por Gaio (Institutiones, IV, 21), e não notaram que a execução a partir de uma damnatio antecedeu historicamente a execução por um iudicium. Noutras palavras, não pode ser considerada pro iudicato uma execução que, quando surgida, não tinha um iudicium paralelo para que fosse comparada. É muito mais crível que o tempo tenha feito com que diminuíssem aos poucos as "causas substanciais notórias", a ponto de introduzir cada vez mais a necessidade de um juízo anterior que servisse de causa à execução e que, assim, homenageasse o valor "segurança" com necessários e indispensáveis procedimentos de cognição judicial. Como se verá em linhas posteriores, a culminação desse processo de eliminação de "causas substanciais notórias" se deu com a publicação da lex Poetelia Papyria (326 a.C.), que parece ter sido o coveiro da manus iniectio ex damnatio.

Destarte, seja no votum, seja nos legados per damnationem e sinendi modo, seja no nexum, a presença da damnatio servia de "causa substancial notória" à instauração de uma manus

\footnotetext{
Dentre eles, pode-se dar destaque a Giovanni Pugliese (Il processo civile romano: le legis actiones. Roma: Ricerche, 1961-62, p. 309), Carlo Augusto Cannata (Profilo istituzionale del processo civile romano: le legis actiones. Tonino: Giappichelli; 1980 , p. 38, nota 1) e Bernardo Albanese (II processo privato romano delle legis actiones. Palermo: Palumbo, 1993, p. 49-50).
} 
iniectio, pois indicava que uma garantia para cumprimento de certas promessas havia sido instituída - pela solenidade de que se revestia e pela presença de testemunhas que the davam publicidade -, nada obstante ser o descumprimento das juras a causa motriz da execução. Sobra, apenas, a necessidade de darem-se breves pinceladas sobre os passos da execução arcaica.

Ela iniciava - seja ex iudicium, seja ex damnatio - com a apreensão do devedor (Lei das XII Tábuas, III, 1-4): o exeqüente tinha a faculdade de apanhá-lo diante do magistrado (iniecere manum), depois que este proferia seu addico, ${ }^{39}$ e levá-lo preso para sua residência, caso não houvesse indicação de garante (vindex). Lá, devia sustê-lo com o alimento necessário, colocálo para trabalhar durante os sessenta dias seguintes, ou então portá-lo diante do pretor por três vezes seguidas, para que fosse noticiado publicamente, em dias de comício, o débito ainda existente. Eram essas as oportunidades para que alguém pagasse o quantum devido pelo aprisionado, sob pena de ser morto ou vendido como escravo (Lei das XII Tábuas, III, 5). As fontes ainda noticiam que se existissem vários credores, o corpo do devedor podia ser dividido em tantas partes quantos fossem os créditos (Lei das XII Tábuas, III, 6).

\footnotetext{
${ }^{39}$ Era necessário que o magistrado pronunciasse o addicere, um dos thid verba legitima, para que imantasse a conduta executoria de legitimidade É que addictio exprimia ldéia de sobreposiçắc ao dicere do privado de um outro dicere por parte do magistrado, que confirmava autontativamente as últimas palavras da legis actio pronunciada pelo autor (tibi manum iniclo), e assim permitia o apossamento do réu por parte do autor (ALBANESE, Bernardo, Il processo privato romano delle legis actiones, cit., p, 44). A funçào pretoriana na manus iniectio, portanto, era autorizar o credor e mandar o devedor năo resistir. Ao lado disso, a lei exercia papel de limitador da conduta humana, ao dispor, com rigide $z_{\text {, }}$ as exatas formalidades que $\mathrm{O}$. atuante devia obedecer para que pudesse implementar forçadamente a prestação acertada. Dentre os romanos, assim como nos primórdios da evolução jurídica germana, o poder coercitivo da forma era chamado para representar esse papel, que em tempos mais avançados seria incorporado como dever de um vigoroso e onipotente Estado (ENGELMANN, Arthur; et alii. History of continental civil procedure (trad. Robert Wyness Millar). Nova lorque: Rothman Reprints e Augusts M. Kelley, 1969, p. 373).
} 


\section{A Condenação Pecuniária das Fórmulas}

As consideraçōes introdutórias deste trabalho já haviam antecipado: seu intento principal é verificar de que maneira a damnatio arcaica passou à condemnatio dos tempos clássicos. Seu fim imediato é abordar a evoluçäo da palavra e o engen. dramento da condenação formular, interessando-se precisamente pela fraçâo de transiçăo que se posta no entremeio dos períodos históncos, e que revela - sem sombra de dúvida - a verdadeira feição jurídica (prática e teórica) que o instituto possuía para os romanos. A análise dessa evolução, porém e por questões de método -, pressupõe que se tenha em mente a situaçáo da palavra em ambos os períodos: a damnatio na fase das açōes da lei e a condemnatio na época das fórmulas. Visto o arcaísmo, cabe agora empurrar os portôes dos tempos clássicos de Roma e adentrar na era do bem acabado processo per formulas, e dele extrair a configuração da condenação como elemento da fórmula e da sentença.

Esse duplo sentido que o vocábulo condemnatio assumia está presente em certa passagem das Institutiones gaianas (IV, 43): Condemnatio est ea pars formulae, qua iudici condemnandi absolvendive potestas permittitur ("a condenação é a parte da fórmula com a qual se atribui ao juiz o poder de condenar ou absolver"). Não que seja petiçăo de princípio, mas a condemnatio era indissociável tanto da arte do praetor (como parte da fórmula) quanto do ofício do iudex (como sentença antagônica à absolutória); ela era pars formulae e sententia ao mesmo tempo, e por isso utilizada em sentidos e para fins diversos. É isso que será visto individualmente a partir de agora.

3.1 A condemnatio enquanto elemento da fórmula e o ofício do pretor

O texto gaiano menciona a condemnatio como sendo a parcela formular responsável por outorgar ao juiz o poder de proferir uma sentença. Acabou que à fração da fórmula, por evolução do direito e pela tendência crescente a abstrações, 
foi dado o mesmo nome da própria sentença de condenação. E tanto é assim que a parte da fórmula denominada condemnatio é a parțe em que está presente a previsão da sentença de condemnatio, como se vê dos seguintes exemplos deixados por Gaio (IV, 43): (...) velut haec pars formulae: IVDEX, NVMERIVM NEGIDIVM AVLO AGERIO DUMTAXAT X MILIA CONDEMNA, SI NON PARET, ABSOLVTO; idem haec: IVDEX, NVMERIVM NEGIDIVM AVLO AGERIO CONDEMNATO et reliqua, ut non adiciatur DVMTAXAT X MILIA ("como a seguinte parte da fórmula: tu, juiz, condena Numerio Negidio a pagar dez mil sestércios a Aulo Agerio, e se assim não parecer, absolve-o; ou também: tu, juiz, condena Numerio Negidio a pagar a Aulo Agerio até a quantidade de dez mil sestércios, e se assim näo parecer, absolve-o; ou também: tu, juiz, condenarás Numerio Negidio a pagar a Aulo Agerio, etc., sem adicionar: até a quantidade de dez mil sestércios"). Como se vê, todas as citações que o jurista romano efetuou não plasmam fómulas inteiras, mas apenas suas parcelas conclusivas, em que o núcleo é a expressa alusão à sentença condenatória ou absolutónia que o iudex devia proferir. ${ }^{40}$

Se a definiçẫo de condemnatio como pars formulae por um lado não chega a revelar a completa aplicação da palavra na época formular, por outro fornece indicaçöes de que é a sentença de condemnatio que deve constituir o objeto da investigação mais detida. Ainda assim, o conceito que Gaio traz à tona contém alguns elementos que merecem breves explanaçōes, seja para dissecar a que contingência processual o jurista se referia, seja para colher o ensejo e desde já

\footnotetext{
40 Para que se perceba o enquadramento da condemnatio na universalidade da formu la, basta cítar passagem de Arthur Engelmann em que há exemplificação e dassificação de todas as partes formulares (de acordo com as definiçöes gaianas) : "Octavius judex esto. Quod Ao. Ao. Cum No. No. fundus Titianus communis est, quo nomine A. A. Num. Num communi dividundo provocavit, qua de re agitur (demonstratio), quantum paret ob eam rem alteri ab altero adjudicari alterurnve alteri condemnari oportere ex fide bona (intentio), tantum, judex alteri ab altero adjudicato (adjudicatio) tantique alterum alteri condemnato, si non paret absolve (condemnatio) (ENGELMANN, Arthur, History of continental civil procedure, cit., p. 294).
} 
suscitar alguns pontos que terâo de estar frescos à mente em momentos posteriores deste trabalho Quando ele escreveu que "a condenaçāo é a parte da fórmula com a qual se atribui ao juiz o poder de condenar ou absolver" (IV, 43), tinha como pressuposiçóes o conceito de fórmula, o sujeito do qual partia a atribuição de poder e a própria consistência desse poder que era repassado ao juiz E é exatamente sobre essas pressuposiçốes que falar-se-á a partir de agora, vendoas da maneira entrelaçada com que se apresentavam nos idos formulares do processo romano.

O nascimento do pretor e da fórmula fol resultado de um período histórico em que nítida laicizaçâo era operadà nas instituições de Roma. Direito e religião se divorciavam; influxos helenizantes incutiam idéias de sistematicidade $\mathrm{e}$ racionalidade de forma a modificar sobremaneira a maior parcela dos institutos jurídicos romanos. ${ }^{41} \mathrm{~A}$ própria criação do pretor, no ano de 367 a.C., (leges Licinniae Sextae) é mostra nítida desses tempos de renovação: as açốes da lei mais e mais se tornavam insuficientes à resolução de conflitos cada vez mais complexos e variados, e ficaram como que um "insuportável casaco apertado" cuja libertação só viria com a outorga de amplos poderes à novel magistratura. ${ }^{42}$

\footnotetext{
4 Trata-se do penodo dito "helenístico', durante o qual houve verdadeiro movimento intelectual em prol das idéias de proveniência grega. No sentido racionalizante, parece ter tido a dialética cabal importância às distinçôs e sínteses que paulatim sistematizavam o direito romano e lhe incutiam cada vez mas uma tez cientifica. (SCHULZ, Fritz. Histony of roman legal science. Oxford: Clarendon Prcss, 1967, p. 62 69).

${ }^{42}$ A divertida metafora $e$ de Arthur Fngelmann (History of continental civil procedure, cit., p. 386). Nă e errado, mas enriquecedor, atribuír a criaça do pretor também ao afastamento cada véz maís seguido dos consules, que tinham de batalhar no front e nẵ mais possuíam rempo para permanecer em Roma exercendo a iurisdictio (D. 1.2.2.27). Somam-se a isso os movimentos populares da epoca, que mais e mais clamavam por espaço na politica citadina. De fato, a criação da pretura parece ter sido pertinente ao patriciado romano, uma breve amenização acs anseios da plebe em acessar o consulado. Sobre isso, veja-se Tito-Livio, $A b$ urbe condita, V, 42, 10 , com interpretaçóes de Vittorio Scialoja (Frocedimiento civil romano: ejercicio y defensa de los derechos, cit, p. 108) e Marlo Talamanca et ali (Linecimenti di storio del dirito romano. 2. ed. Milano: Gutufrè, 1989, p. 131).
} 
Conforme indicação da romanística, o antigo processo das legis actiones apresentava duas gravissimas insuficiências e por isso clamava por mudanças: (a) nenhuma das ações possibilitava a tutela de um incertum, isto é, dos novos contratos que brotavam das relaçōes comerciais desenvolvidas; e (b) das ações da lei só podiam participar os cidadãos romanos. 43

Nesse sentido, o aparecimento do pretor casa bem com os anseios da época em preservar as antigas instituições (as açôes da lei), mas, por outro lado, em estendê-las de modo que pudessem se readequar à nova realidade. É interessante notar que através das mesmas leges Licinniae Sextae foi introduzida a legis actio per iudicis arbitrive postulationem, instrumento que possibilitava a quantificaçâo pecuniária de um incertum e que - como se verá no decorrer deste trabalho teve magna importância para a engendração da condemnatio clássica e para o próprio aparecimento das fórmulas. ${ }^{44}$

Já a segunda insuficiência das legis actiones foi suprida com a criação do praetor qui inter peregrinus ius dicit, ${ }^{45} \mathrm{em}$ 242 a.C., conforme revela trecho do Digesto (D. 1.2.2.28). Acudindo a inacessibilidade dos estrangeiros ao antigo procedimento, essa nova magistratura revestia-se de um todo novo

\footnotetext{
43 CANNATA, Carlo Augusto. Profilo istituzionale del processo civile romano: il processo formulare. Torino: Giappichelli, 1982 , p. $50-51$.

4 E bastante ilustrativo apontar gue nesses mesmos tempos um romano de nome Cneus Flavius, secretărio do jurisconsulto Appus Claudius Caecus, publicou o calendáno pontifical e um livro com as fómulas processuais detidas pelos sacerdotes (D. 1.2.2.7), circunstância que é considerada um marco na secularizaça das instituiçóes jurídicas de Roma. For isso, pode-se dizer com Greenidge: "Procedure is always a symbolic manifestation of right $($.$) .) When the initial difficulties have been overcome$ - when the religion has been relegated to its proper place, when fas has a sphere distinct from ius, when the exclusive privileges of the legal guild or other interpreter have been broken down, and writing can be used for documentary evidence and for instruction - then the development of procedure is one of the surest signs of the development of law" (GREENIDGE, Abel H.J. The legal procedure of Cicero's time. Oxford Clarendon Press, 190I; p. 3-5).

45 A conhecida denominaçäo praetor peregrinus' só apareceu nos primeiros anos do Principado, conforme indicaçöes de Feliciano Serrao (SERRAO, Feliciano. La iurisdictio del pretore peregrino. Milano: Giuffrè, 1954, p. 19).
} 
modus agendi, muitissimo mais livre, adaptável à mentalidade e aos costumes de povos diversos (já que seus destinatários eram estrangeiros), desatrelado do rígido ius civile que dava sustento às ações da lei ${ }^{46}$ Nele parece ter brotado o primeiro ramo efetivo do que mais tarde seria o processo formular: a atuação do pretor peregrino era livre de leis e formas prédeterminadas, baseada tão-somente no caso concreto que as partes the apresentavam.

"É natural que sob as influências do novo modus agendi", afirma Serrao, "com o qual litigavam os estrangeiros excluídos dos institutos civilísticos, o formalismo do lege agere começasse a parecer inadequado à regulação das relações entre os membros de uma sociedade mais evoluída". ${ }^{77}$ Assim, năo tardou muito e ambas as magistraturas - pretor urbano e pretor peregrino - se fundiram numa só, principalmente depois de possibilitada a intercessio entre elas (Cícero, In Verrem, II, 1, 46, 119; Júlio César, De bello civile, III, 20). A irreversível decadência das legis actiones culminou com a publicação da lex Aebutia (entre 149 e 126 a.C.) e das leges luliae iudicionum (17 a.C), a uniformizarem os procedimentos, revogarem açōes da lei e reconhecerem como universalizado o modus agendi do pretor peregrino, ${ }^{48}$

\footnotetext{
46 SERRAO, Feliciano, La iurisdicto del pretore peregrino, cit. p. 37 Aqui ressaltam as diferencas entre iudicum legitimum (processo instaurado em Roma com juiz singular na fase apud ludicem e tendo cidadãos romanos como partes) e iudicium quod imperio continetur (ante a falta de qualquer dos elementos que lapidavarn o fudicium legitimum), O pretor peregrino, logicamente, exercia seu oficio dentro dos lindes do iudicium quod imperio continetur (SCHULZ, Fritz, Derecho romano clásico, cit, pi17).

47 SERRAO, Feliciano, La urisdictio del pretore peregrino, eit, $\mathrm{p}, 51$

* Por óbvio que nâo se deve imputar a ditas leis as modificaçốs que outrora se acreditava terem delas derivado. Os romanos não legislavam para modificar $o$ estado de coisas, mas para reconhecer e oficializar costumes desde muito em voga. Nesse sentido, 11 processo formulare è preso in considerazione come entità già esistente, di consistenza tale da poter concorrere con le legis actones, imponendo; a poco a poco (paulatim) le sue migliore gualita, la sua ldoneita ad una tutela dei diritti commodius et plenius" le leggi ebuzia e giulia sono leggi che abrogarono legis actiones, non que introdussero o sanzionarono azioni formulan' (CANNATA, Carlo Augusto, Frofilo istituzionale del processo privato romano: il processo formulare, cit, pp 51-52). Cr também Gaio, Instilutiones, IV, 30.
} 
Observados alguns traços de sua evolução, é hora de verificar em que consistia propriamente o oficio do pretor no processo formular. Parecia estar ele embasado em dois imprescindiveis fatores: no imperium outorgado pelo povo e na auctoritas partilhada pelos jurisconsultos. ${ }^{49}$ Pela circunstância de ser eleito por assembléia popular (Comitium Centuriatum), - magistrado nâo exercitava um poder próprio, mas o poder

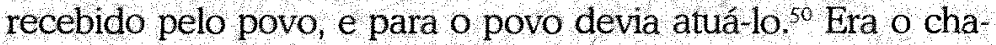
mado 'imperium', do qual participava com especialização na iurisdictio (ou mixtum imperium, conforme D. 2.1.3), e que historicamente brotou do reinado etrusco sobre Roma e fracionouse nas diversas magistraturas que com a República tiveram advento. Pela circunstância de ser auxiliado por um consilium de jurisconsultos, o pretor adquiria embasamento técnico para o exercício de suas funções: revestia-se de auctoritas, princípio gerador de obediência, ordem e disciplina dentre os destinatários de seus provimentos. ${ }^{51}$

\footnotetext{
49. Disso fazem prova duas passagens de Cícero: a primeira (De legibus, III, 1, 2), abordando a natureza essencial do imperium, bem como descrevendo o magistrado como legem loquentem ("a lei que fala") e a lei como mutum magistratum ("o magistrado silencioso ); a segunda (De legibus, III, 2, 5), indicando aos cidadãos que não devem apenas obedecer aos magistrados, mas amá los e respeitá-los como às proprias leís.

50 GALLO, Filippo. Lofficium del pretore nella produzione e applicazione del dirito. Torino P. Glappichelli, 1997, p. 28. Uma bela passagem de Isidoro relaciona com primor os elementos que fundamentavam o imperum ex innocentia nascitur dignitas, ex dignitate honor ex honore imperium, ex imperio libertas (Isidorus Hispalensis, $E$ libris originum s etymologianum, II, 21,4). Here personal virue (innocentia), once recognized (dignitas), leads, by in the state by way of the magistracy voted to the individual by the people (honor), to the acquisition of power in the state by the individual (imperium), and thus to the culmination of the list with the freedom which guarantees not only the position of the state with regard to other states, but also the position of the individual within it. The crucial link in the ascending sequence is that between the individual and the state, and that is represented by honor and imperium. magistracy and power (RICHARDSON, J S Imperium Romanum empire and the language of power The Joumal of Roman Studies, 1991, v. 81, p. 4).

5r SCHULZ, Fritz Principles of roman law (trad Marguente Wolf). Oxford Clarendon Press, 1956, p. 164. Conforme bem resume Levy-Bruhl, "rien ne permet de supposer que le Preteur, conscient de son nfériorite technique, nait suivi docilement les conseils du Prudent consulté (LEVY-BRUHL, Henri. Prudent et préteur. Reuue histonique du droit français et étranger. Paris: Recueil Sirey, 1926, ano 5, p. 36).
} 
$O$ exercício pelo pretor do nicho jurisdicional aglutinava três deveres sucessivos: (i) detectar a tutelabilidade das pretensōes expostas pelo autor, (ii) prestar orientações na redação da fórmula e (iii) autorizar a instauração de um juízo posterior. Cada um desses deveres receberá apreciação pontual nos parágrafos que seguem.

Num primeiro momento, o pretor tinha de verificar se os relatos do autor eram tuteláveis, tomando-os como se fossem absolutamente verdadeiros e verificando se um juízo imparcial era necessário e harmônico ao direito reconhecido. Não sendo digna de proteçâo processual, a actio era denegada pelo magistrado (denegare actionem). ${ }^{52}$ Fica claro, portanto, que ao pretor não interessava se o autor tinha ou não razão nas alegaçōes que expunha; seu ofício era observar, apenas, se as pretensóes cumpriam com alguns requisitos formais, bem como se não estavam em desacordo com o direito reconhecido.

Superada a admissibilidade, passava-se à redação da fórmula, da qual participavam os disputantes - futuros autor e réu - e principalmente o magistrado, aqueles apresentando e modificando a narrativa fática, e este introduzindo correçôes e adaptações de cunho técnico - por força do auxîlio dos jurisconsultos - ao bom norteamento do procedimento apud iudicem. ${ }^{53}$ A fórmula, como se vê, era fixada para o

\footnotetext{
52 Max Kaser indica uma serié de circunstâncias que poderiam redundar numa denegatio. São elas: (i) näo previsão no Edito e impertinência de se deferir uma actio in factum; (ii) exposiçáo defeituosa dos fatos: (iii) requerimento de uma actio inadequada; (iv) ilegitimidade de partes; (v) falta de un dos requisitos processuais, quais sejam, pertinencia legal do processo (a preterisäo do autor devia pertencer ao campo próprio do processo formular, e nầ à seara penal ou administrativa), competência do magistrado por razâo da matéria competência do magistrado por razâo do lugar e capacidade das partes (KASER Max. Derecho romano privado (trad. José Santa Cruv Teijeiro). 5. ed. Madrid: Reus, 1968 , p. 363-364). Sobre actio, este trabatho adota as percepcóes de Fritz Schulz (SCHULZ, Fritz, Derecho romano clásico, cit., p. 23-24), e presta ainda homenagens à ótima crítica que faz ao conceito celsino (D. 44.751), que assoma hoje como espúrio e desconexo da realidade cássica (SCHULZ, Fritz, Principles of roman law, cit, p. 44.45).

53 Cf. SCHULZ, Fritz, Derecho romano clásico, cit, p. 18. Na esteira, o romanista tece otimas críticas ao falido modelo arbitral de Moriz Wlassak, do qual deconia a visão da fómula e da litis contestatio como um contrato ou um quase-contrato (p. 15-16).
} 
caso concreto: redigida a partir da narrativa fática das partes e orientada à resolução do conflito específico. $O$ escopo disso tudo não era a elaboração de noçōes jurídico-abstratas, mas simplesmente a justa pacificação das relações supostamente em turbulência. Sobre isso, as seguintes palavras de Filippo Gallo configuram ótima suma: "o direito romano, em virtude da iurisdictio pretória, não corresponde nem a um sistema de estirpe normativista, nem a um sistema de estirpe casuísta; ele oferece um terceiro modelo (...), no qual a base normativa se conjuga à criação do direito no caso concreto (quando isso for resultado da própria finalidade do direito, consistente na atuação, em nível concreto, do bonum et aequum)". ${ }^{54}$ Exsurge a atividade pretória como indicativa do justo abstrato, modelo orientador do juiz à realização concreta do bom e do eqüitativo. ${ }^{55}$

Ao pretor, portanto, não interessava qual das partes estava com a razão, pois a perquirição dos fatos fazia parte do procedimento apud iudicem. Seu ofício era de índole legislativa concreta: ouvia a narrativa das partes e com elas compunha a fórmula, indicando o justo abstrato que serviria de modelo ao juiz quando no conhecimento do conflito e na lapidação da sentença, ${ }^{56}$ tanto quanto apontando para os

\footnotetext{
54 GALLO, Filippo, Lofficium del pretore nella produzione e applicazione del dirito, cit., p. 55 , nota ${ }^{\circ}{ }^{\circ} 6$.

5s Novamente, sào as brilhantes afirmaçöes de Filippo Gallo que complementam $\emptyset$ tópico: "L'aspetto o elemento essenzale del dinitto non è ravísato nella norma, nel comando imperativo munito di sanzione, bensi nellars, nellinsieme delle conoscenze e tecniche ocorrenti per realizare, nel rapporti umani, il bonum et aequum. Lars mette in luce il ruolo dell uomo nella produrione, come nell applicazione, del dirito, che non viene visto, in contrasto con la realtà, come un fenomeno statico, bensi, in aderenza ad essa, come un fenomeno in divenire. La posizione delle nome e la iurisdictio, entrambe rientranti nel ius, mirano congiuntamente all'indicata realizzazione" (GALLO, Filippo, Lofficium del pretore nella produzione e applicazione del dirito, cit., p. 55). O elogiável trecho vai na esteira de conhecida disposição de Celso (D. 1.1.1): (...) nam ut eleganter Celsus definit, ius est ars boni et aequit (...porque, como define elegantemente Celso, o direito é a arte do bom e do equitativo $)$. $O$ pretor dizia o direito, isto e, indicava a arte (conjunto de técnicas) de realizar concretamente o bom e o eqúitativo.

so Tanto que das fórmulas constava a expressão "si paret" ("se é manifesto") antecedendo a enunciaçäo da causa segundo a qual se agla - cousa ex quo qgebatur (CANNATA, Carlo Augusto, Proflo istituzionale del processo privato romano: il processo formulare, cit., P. 74).
} 
instrumentos pelos quais esse conflito deveria receber pacificaçầo. Destarte, ao contrário da situaçăo hodierna, em que há prévia e reconhecida separação teórica entre direito material e processo, no direito romano, ambos eram manifestados concomitantemente pela fórmula, pois o escopo da atividade pretória não era científico, mas prático. Porém, ainda assim, sob a óptica atual, pode-se identificar (como recém-feito) os campos em que se manifestavam o substancial e o instrumental no direito romano, pois como compo nentes da natureza das relaçôes humanas, pertencem à parcela invariável do jurídico.

Esse "formalismo funcional" 57 do processo per formulas estava todo centrado no papel da intentio, isto é, na parte da fórmula que exprimia a pretensão do autor (Gaio, Institutiones, IV, 41), a causa ex quo agebatur. Era pretensāo enquanto descrevia a situação ideal que o autor perseguia caso a iniqüidade concreta restasse comprovada; mas também era causa de agir enquanto norteava todo o procedimento posterior, a fazê-lo convergir para a confirmação ou à negação do que nela vinha descrito. Por isso diz-se que a intentio era o único fragmento do qual nấo se podia prescindir na redação de uma fórmula; por isso que sua confirmaçăo gerava uma sentença de condemnatio, e sua negação, uma absolutio.

Redigida a fórmula, era hora de se pensar na fase julgadora, e daí brotava a necessidade de escolher-se um iudex para a conduçấo do procedimento conseguinte. ${ }^{58}$ Parece que a seleção incumbia às partes, desde que referendada pelo pretor. Se houvesse concórdia, ela recaía ou sobre uma

\footnotetext{
${ }^{67}$ A expressáo é de Dario Mantovani, que afirma ser of formalismo formular eminentemente funzionale a conservare il punto di equilibno fra le istanze di adatiamento dellordinamento, cui dava voce il pretore (e, piu in generale, i magistrati giusdicenti), e l'esigenza, consapevole o meno, di certezza del dirittó (MANTOVANi, Dario Le formule del processo privato romano. 2. ed. Padova: CEDAM, 1999, p, 22).

s\$ Sobre o ponto, vale indicar que diversos romanistas divergem sobre a necessidade em anotar-se expressamente na fómula o nome do juiz que julgaria o feito As recentes descobertas arqueológicas pouco contribuiram à solução do problema. Para resumo dessas discussôes sob a luz da lex Imitana, veja-se METZGER, Ernest. A new outline of the roman civil trial Oxford: Clarendon Press, 1997, p. 71-75.
} 
pessoa pré-eleita pelos disputantes, ou sobre um dos nomes constantes do album iudicum, fazendo-se indispensável sua presença já no ato de litis contestatio. Daí porque o procedimento in iure já pudesse ser encerrado se o iudex estivesse presente, mas o corriqueiro era que o pretor, depois da indicação de um dos nomes constantes no album, deferisse três dias de intervalo (intertium) para que fosse verificada a disponibilidade do futuro juiz..$^{9}$ Comprometidas por promessas (uadimonia), as partes retornavam no dia marcado para a nomeação magistratural do iudex (por meio de addicere, que şimbolizava a transferência de imperium judicativo), realizavam a litis contestatio, davam por encerrado o procedimento in iure e adentravam no julgamento propriamente dito.

Caso não houvesse concórdia entre as partes acerca do nome do juiz, era necessário que se observasse um procedimento através do qual chegava-se à conclusão pór exclusões e rejeiçôes (por isso o nome de relectio). Porém, se alguma das partes se recusasse a seguir dito procedimento, a indicação do iudex passava ao arbítrio do pretor, que o fazia a partir do album iudicum. Por força da lógica, também aqui o deferimento de intertium fazia-se necessário. $E$, enfim, depois da litis contestatio, ao julgamento se passava.

Em poucas palavras, parece ter sido esse o ofício do pretor na época formular de Roma. Seguindo um movimento natural, sua liberdade criadora foi paulatinamente substituída por generalizações e abstrações, ante a repetição dos

${ }^{5}$ E dessa maneira que relata Ennest Metager baseado principalmente no capítulo 90 da lex Irnitana. Segundo o autor, "the interruption is made necessary by the inherent awkwardness in selecting judges unless the parties have agreed on a person to serve and he is amenable to selection as a judge, that person cannot be appointed asjudge on the spot. The person whom the parties might wish to select, or the person whom the retectio procedute produces, could be dead, ill absent from the town, or have suffered a loss of status. An interruption before litis contestatio gave an opportunity to consider his availability to serve as a judge" (METZGER, Ernest. Interrupting proceedings in iure vadimonium and intertium. Zeitschrift fur Papyrologie und Epigraphik, n. ${ }^{\circ} 120,1998$, p. 217).

60 Para esses apontamentos, veja-se METZGER, Emest, A new culline of the roman civil trial, cit, p. 62 . 
conflitos e de suas soluçóes: primeiro se lhe impuseram os editos anuais (lex Cornelia, 67 a.C.); depois, adveio um Edictum Perpetuum que petrificou seus provimentos (elaborado pelo jurisconsulto Sálvio Juliano, em $117 \mathrm{~d} . \mathrm{C}$, às ordens do imperador Adriano) $)^{61}$; e por fim, Constâncio e Constante, por meio de suas constituições ( 342 d.C.), proibiram expressamente o uso das fómmulas processuais, reconhecendo, com atraso, a morte de um magistrado que há tempos já figurava apenas como relíquia dos velhos tempos. Pois fórmula e pretor nasceram e pereceram juntos. ${ }^{62}$

\subsection{A condemnatio enquanto espécie de sentença}

À instauração do procedimento apudiudicem, com a celebraçăo da litis contestatio e com a escolha de um iudex, sucediam-se os atos de julgamento, nestes inclusos a exposição ao juiz da causa ex quo agebatur (causae coniectio), a produção de provas e o efetivo sentenciamento. Todos esses passos estavam centrados na intentio formular, já que pars formulae expressiva da siruaçấo examinanda, ou seja, da obrigação que supostamente existia em benefício do autor e que fora descumprida pelo réu. Se fosse manifesta sua existência, o juiz tinha de condenar o requerido; caso contrário, absolvê-lo (si paret, condemnato; si nơn paret, absolvito). Por isso, era mister das partes tornar manifesta ou improvável a existência de uma obrigaçâo descumprida (aludida na

\footnotetext{
${ }^{61}$ Abel H: J. Greenidge consegue explicitar ainda melhor o inicio dessas abstrações, afirmando que o pretor, no aperfeicoamento de seu uits honorarium, procedia do particular para o geral. Quando alcancado o estágio de editos, não remanescia qualquer dưvida acerca de sua preponderância sobre a simples fómula (GREENIDGE, Abel H. J., The legal procedure of Cicero's time, cit. p. 89).

*as seguintes observaçoes de Arthur Engelmann são bastantes apropriadas ao ponto: "The day finally came when the magistrate was no longer in position to command by his formula that the judge apply a principle not already known to him. The judge now would not only have known the principle but would have been independently bound to apply it, because it was part of the statutory law. The formula thus lost its significance as an expression of the law willed by the State for application to the case in hand I regulation of the transaction there involved. (...) it was inevitable that the formula should be looked upon as an antiquated and superfluous institution and the separation of the proceeding into jus and judimum" (ENGELMANN, Arthur, History of continental civil procedure, cit., p. 318 ).
}

Cadernos do PPG em Direito UFRGS, Porto Alegre, v. 6, n. 7 e 8, p. 223-291, 2007. 
intentio), e isso era feito por meio da produção de provas perante o iudex. O procedimento apud iudicem era todo embasado na verificação da correspondência entre intentio e fatos.

Para alcançar um convencimento súficientemente seguro, o juiz não se municiava apenas das alegações e das provas, mas também do auxilio de um consilium de jurisperitos e de seus próprios conhecimentos técnicos que, com o passar dos séculos, iam se aprimorando. ${ }^{63}$ Todos esses compostos formavam a solução final do litígio: uma condemnatio, uma absolutio ou a declaração de que rem sibi non liquere ${ }^{64}$ Ao presente trabalho interessa eminentemente o primeiro desses desdobramentos: a sentença de condemnatio.

Antes de tudo, é importante observar que a sentença do iudex romano era talhada como documento escrito, apesar de a escritura não ser um de seus requisitos formais, $\mathrm{e}$ depois de pronta era pronunciada oralmente na presença das partes. ${ }^{65}$ Era motivada, não obstante a motivação não ser exigência dos tempos de ordo iudiciorum, mas impulsionada pelo medo que tinham os juízes de contra si ser processada uma actio si iudex litem suam fecerit. ${ }^{\text {so }}$

Como aponta Max Kaser já na análise interna da sentença, ela possuía 'força jurídica formal' (pois definitiva, inalterável, irrecorrivel) e 'eficácia jurídica material' (pois influía na seara jurídico-material, colocando termo ao conflito e realizando concretamente o justo abstrato descrito na fórmula). ${ }^{67}$ Nada mais era do que o resultado da cognição do juiz: se positiva (a intentio de fato procedia, havia uma obrigação descumprida), lapidava-se uma condenação; se

\footnotetext{
${ }^{63}$ E o que confirma Aulo Gélio em trecho das Noctes Atticae (XIV; 2$)$.

t4 $O$ non liquet se dava quando, para o juiz, a causa näo estava suficientemente esclarecida a ponto de assegurar uma sentença justa. Por isso, ele jurava não estar apto para decidir delinitivamente o feito (Aulo-Celio, Noctes Atticae, X1V, 2).

65 Conforme apontamentos e fontes citadas por VILLAR, Alfonso Murillo, La motivación de sentencia en el proceso civil romano. Cuadernos de historia del derecho: Madrid: Complutense, 1995, n. 2, p. 13.

to VILLAR, Alfonso Murilio, la motivación de sentencia en el proceso civil romano, cit., p. 19.
} 
negativa (o dever não existia ou, entäo, ele fora córretamente cumprido), uma absolvição. Mas não consistia em mero silogismo, como acreditavam noutros tempos alguns romanistas alemães: mormente porque existia uma variedade considerável de escolas jurídicas, o ofício do juiz não tinha como ficar adstrito a atuaçóes robóticas, já que, diante de conflitantes interpretaçōes, ele tinha de optar pela que lhe parecia oportunizar de maneira mais adequada a realização do justo concreto ${ }^{68}$ Como aponta Ernest Metzger, as falhas da romanística alemã nessa matéria resumem-se na crença de que o juiz só decidia fatos e nunca matéria jurfdica, e que era ele absolutamente ignorante em questões técnicas ${ }^{69}$ Felizmente, descobertas posteriores da arqueologia andaram cada vez mais em sentido diverso. ${ }^{70}$

Essa sentença, portanto, que não resultava de um silogismo, mas do cotejo balanceado de intentio, alegações, material de prova, pareceres de jurisconsultos e conhecimento técnico prévio s e que decorria da detecção do descumprimento

\footnotetext{
67 KASER, Max, Derecho romano privado, cit, p. 378.

6.8 Dois dos mais importantes representantes da Escola Histónca do Direito, Savigny e Puchta, se opunham à participaçăo dos juíres na construçâo e no desenvolvimento jurídico de Roma, posicionamento imantado de carga ideológica, como demonstra James $\mathbf{Q}$. Whitman (WHITMAN, James Q. The legacy of Roman Law in the German Romantic Era: historical vision and legal change. Princeton: Princeton University Press, 1990, p. 130-131).

${ }^{69}$ METZGER, Ernest Roman judges, case law, and principles of procedure. Law and history review (separata), 2004, $n .22 / 2$, p. 17-18.

70 Faz-se aqui alusão aos papiros descobertos no Egito durante o século XX, na área que fazia parte da antiga cidade de Oxynhynchus. Como noticia H. F. Jolowicz, eles denunciam a prática de citar precedentes adotada por diversos iudices romanos (JOLOWICZ, H. F. Case law in roman Egypt. The joumal of the Society of Public Teachers of Law. [s.1]: [s.n.], 1937, r. 14, p. 2). Mas quando se fala em precedentes, não se está querendo dizer que as sentenças exaradas faziam direito às futuras decisoes. Nesse ponto, a doutrina tradicional parece estar correta, jă que a criação do direito não era oficio dos iudices, e tanto por isso qualquer manifestaçăo comparativa ao cose law anglo-saxônico ế no mínimo absurda. Porem, como assevera Ernest Metzger, não é impossivel a existência de juizes que, após a laicização do direito e com a crescente liberdade interpretativa, pudessem optar por posicionamentos jurisprudenciais diversos, escother para sua sententia uma dentre as tantas ppiniöes dos jurisperitos à época existentes (METZGER, Emest, Roman judges, case law, and principles of procedure, cit., p. 11).
} 
de uma obrigação, era denominada condemnatio, e é ela que interessa especialmente a este trabalho e compóe seu núcleo central. Por ora, o importante é analisar o que causava seu proferimento e as conseqüências mediatas que era capaz de engendrar na esfera processual. Sua natureza obrigacional, porém (e portanto sua substância), será objeto de apontamentos nos últimos capítulos deste trabalho.

Sendo a condemnatio a culminação positiva da cognição do iudex, apresentava não apenas a confirmação de que existia um dever, mas principalmente de que de fato ele fora descumprido pelo réu, e que assim merecia ajustes forçados. Configurava a conseqủência inequívoca da manifesta correspondência entre causa (intentio) e realidade (injusto concreto). Enquanto estivesse previsto na fórmula, por exemplo; que N.N. devesse ser condenado caso fosse manifesto o inadimplemento de um aluguel (uma formulação condicional), na sentença de condemnatio, dizia-se que N.N. era devedor e por isso estava condenado ao pagamento da quantia faltante (uma formulação imperativa) - se, por acaso, a instrução do processo pendesse nesse sentido, por óbvio.

Sobre seu aspecto externo (porque o interno, tocante à sua obrigacionalidade, será visto em ponto posterior), é pertinente lembrar que nos idos formulários toda sentença condenatória trajava vestimenta pecuniária. Isso porque o nível de abstração jurídica desses idos - conseqüência de uma sociedade mercantil e urbanizada, tendente a transformar todo valor em moeda - admitia como idônea a compensação em dinheiro da lesắo sofrida, e por isso é possivel dizer que o escopo da condenação no processo civil da época era "restabelecer o equilíbrio econômico entre as partes, interrompido por abuso anterior", como fez Angela Romano. ${ }^{71}$ A pecuniariedade da sentença assumia alguns aspectos relevantes conforme se delineasse o caso concreto, e é isso que agora será visto em breves comentários.

\footnotetext{
${ }^{\gamma}$ ROMANO, Angela, Condanna "in ipsam rem" e condanna pecuniaria nella storia del processo romano, cit., p. 1.45.
} 
A regra era a condemnatio certae pecuniae, decorrente obviamente de uma intentio também certae pecuniae. De uma intentio incertae pecuniae (dirigida a uma res ou a um facere) nunca poderia decorrer uma condemnatio incertae pecuniae; era pressuposição que antes de sua prolaçăo se fizesse a transformação da coisa ou do fazer em dinheiro (Gaio, Institutiones, IV, 48), e isso era feito por meio dos expedientes de estimaçăo da lide (antigo arbitrium liti aestimandae, que com o tempo transformou-se em incumbência do próprio julgador, sobretudo depois da legis actio per iudicis atrbitrive postulationem e da conseqüente fusấo entre iudex e arbiter). O momento dessa transformaçăo, portanto, postava-se depois da cogniçăo judicial completa e antes da exaração da sentença de condemnatio, e tinha por limitaçōes as seguintes circunstâncias: (a) havia fórmulas que previam um máximo do qual o julgador não podia ultrapassar na estimação da lide (taxatio), sob pena de litem suam facere; (b) noutros casos, o iudex estava investido de ampla liberdade para quantificar o objeto da demanda, e devia fazê-lo com fundamento na boa-fé (ex fide bona) e na eqüidade (bonum et aequum); ${ }^{72}$ (c) e, enfim, havia hipótese em que a estimação e a conseqüente condenação deviam ser feitas in id quod facere potest, isto é, limitada naquilo que fosse a concreta possibilidade do réu em prestar com efetividade o que devia para o autor, sem onerá-lo para além de suas capacidades. ${ }^{73}$

O procedimento de estimaçẫo da lide poderia ser evitado se, na fórmula, constasse a expressão nisi restituetur ou neque restituetur, que ensejava ao réu que restituísse a própria

\footnotetext{
${ }^{72} \mathrm{E}$ o que consta nas Instintas de Justiniano (4.6.30) In bonge fide autem iudicils libera potestas permifti videtur iudici ex bono et aequo aestimandi quantum actori restitui debeat In quo et illud continetur, ut, si quid invicem praestare actore oporteat, eo compensato, in reliqum is, cum quo actum est, debeat condemnati ("mas nas acoes de boa-fé se entende que se atribui ao juiz a livre faculdade para estimar, segundo o bom e o equitativo, quanto se deva restituir ao autor No que se compreende também que se a sua vez deve o autor pagar alguma coisa, feita a compensação, deva ser ordenado pelo resto contra quem se reclamou").

73. Assim noticia GUARINO. Antonio. La condanna nei limiti del possibile. 2. ed Napoli: Jovene, 1978, p. 8 .
} 
coisa antes da quantificação pecuniária e da exaração da condemnatio. Diante de dita cláusula (também denominada arbitraria), o juiz podia exarar uma ordem (pronuntiatio) para a entrega específica da res; somente se desobedecida é que a sentença era prolatada (I, 4.6.31). Operada a restituição, a sentença era de absolutio, excetuadas custas e penas processuais, que corriam por conta do réu. ${ }^{74}$

Verificada a causa do proferimento de uma condemnatio e também seu revestimento exterior, cabe ainda neste ponto inquirir sobre as consequências mediatas que na esfera processual seu descumprimento era capaz de gerar, e aqui assoma apropriado tecer algumas rápidas considerações sobre a execução de sentença da época formular. Em idos remotos, já a regra decemviral (Lei das XII Tábuas, III, 1-3) estabelecia que, passados trinta dias da sentença sem seu cumprimento voluntário, o autor poderia comparecer em juízo e requerer o início da execução. A disposição - que tratava da manus iniectio - parece ter perdurado imune ao tempo: a actio iudicati (execução da época formular) também pressupunha a passagem dos mesmos trinta dias.

Perante o pedido do autor, o executado podia assumir alguma das seguintes condutas: (a) ceder voluntariamente seu património ao credor (cessio bonorum), usufruindo dos beneficios da condemnatio in id quod facere potest; ${ }^{75}$ (b) submeter-se passivamente à execução, que era coordenada pelo pretor e se baseava na bonorum venditio; ${ }^{76}$ (c) ou contestar a existência do título executivo, determinando a inauguração de um novo iudicium cognitório que poderia resultar ou na

\footnotetext{
7 Essa a opinião dos sabinianos, baseada no brocardo omnia iudicia absolutoria esse (Gaio, Institutiones, IV, 114), que garantiu sucesso frente ao entendimento dos proculeianos.

750 devedor só teria seus bens constritos nos limiles que pudesse suportar, sem que seus mínimøs meios de sobrevivência fossem prejudicados (D'ORS, Alvaro, Derecho privado romano, cit., p. 164).

${ }_{7}$ No processamento da bonorum venditio, o pretor expedia quatro diferentes or dens: em primeiro lugar, outorgava ao credor o poder de se apossar dos bens do devedor (decreto de missio in bona, mas com posse meramente conservadora $e$
} 
acolhida de seus argumentes, ou numa nova condemnatio, mas, desta vez, dobrada (litiscrescência, in duplum) pela negação falsa de uma dívida de fato existente. ${ }^{77}$

E pertinente aludir que a radicalidade da bonorum venditio foi se amainando com o passar dos anos. Conta-se que por volta do ano $100 \mathrm{~d}$.C., um senatusconsultum de Nerácio introduziu o procedimento da distractio bonorum, consistente na venda de bens singulares até que satisfeitos os créditos existentes, $\mathrm{O}$ então novel procedimento era centrado na figura do curator bonorum (administrador interino dos bens) e excluía de pronto a venda universal do patrimônio do executado. ${ }^{78}$

\section{Da Damnatio à Condemnatio}

Como se vế, a existência de uma sentença de condemnatio era pressuposto ao processamento de posterior execução, mas isso năo quer dizer que sua mera presença fosse suficiente. A actio iudicati, em verdade, tinha como causa uma condenação descumprida, e não apenas uma sentença condenatória; seu elemento determinante, portanto, era a desobediência à

\footnotetext{
aưministradora dos bens, rei servandae causa); depois, determinava que os credores se reunissem e elegessem quem procederia a venda do património (o magister bonorum venderorum), a seguir, autorizava a venda; e, por fim, ordenava que a universalidade fosse transferida ao comprador depois que sua venda houvesse sido feita (Gaio, Institutiones, 11. 79). Entre a primeira e a segunda ordens pretorianas, incumbia a credor dar publicidade da tomada da posse e de sua futura alienaçáo (ato chamado de proscriptio), para que a universalidade de credores do mesmo devedor se habilitasse ao recebimento da parcela gue lhes incumbisse De se assinalar, ainda, que o dinheiro da venda era repassado ao magister, que o dividia eqüitatvamente entre os credores, de acordo com a quota de cada um.

"1 possibilidade de oposiça à execucão (infitiatio) desdobrou-se historicamente da figura do vindex arcaico, que adentrava na relação processual enquanto garante, exclúa o réu do feito e tomava seu lugar, já naquela época sujeito a uma sentença com duplum de condemnatio Extirpado o vindex e universalizada a possibilidade de defesa propria do reu (com o desenvolvirnento da chamada manus iniectio pura, en gue o ré se colocava como uindex de si mesmo, manum sib depellere et pro se lege agere), espectalmente depois do advento de uma lex Vallia (Gaio, Institutiones, IV, 25), remanesceu a oportunidade de o executado se opor diretamente ao título execulivo (ALBANESE, Bernardo, 11 processo privato romano delle legis actiones, cit., p. 43-44).

${ }^{78}$ ENGELMANN, Arthur, History of continental civil procedure, cit, p. 380.
} 
sentença, não só a existência dela. Basta referir que na prática processual nem sempre uma condemnatio gerava uma execução, pois ao réu era facultado efetuar o pagamento da soma pecuniária nos trinta dias que se seguiam (Lei das XII Tábuas, III, 1-3). A sentença de condenação daqueles tempos, portanto, nấo pode ser definida como aquela que gerava posterior execução.

Por outro lado, dizer que ela consistia em mera declaração é insuficiente. É certo que o reconhecimento de uma obrigação não cumprida era seu pressuposto, mas essa não parece ter sido sua finalidade. Tal seria desprezar o espírito prático do qual estiveram imantados todos os instrumentos processuais formulares e considerar a verdade como sendo o escopo do processo romano, e năo imediatamente a realização do justo concreto. Ter-se-ia um procedimento voltado exclusivamente à cognição do juiz, que exararia declarações sem estabelecer qualquer liame direto com a situaçẩo concreta. Se no processo civil hodiemo já se tecem sérias reticềncias a concepçốes da estirpe, imagine-se o absurdo de interpretar-se dita realidade como sendo a do processo de Roma, que - como sabido - era desligado da noção de direitos subjetivos e voltado para a praticidade de seus instrumentos.

É preciso descer da superfície à profundidade da condemnatio, e isso passa necessariamente pelo prisma histórico-evolutivo do instituto. De plano, e dado o imperium de que se revestia a atuação do iudex (afinal, ele o recebia do pretor por meio da cláusula formular que "coincidentemente" Gaio chamou de condemnatio), a sentença condenatória parece ter sido um 'pronunciamento que submetia'. É o que se poderá confirmar na evolução da damnatio para a condemnatio, a ser abordada nas próximas linhas, desenvolvimento este que é ilustração e consequêencia da laicização institucional de Roma e da paulatina dessacralização da prática dos magistrados.

Nessa linha, parece ter sido a tendência expansionista dos romanos o elemento que mais contribuiu para o desenvolvimento de suas instituiçôes. A partir do século $\mathrm{V}$ a.C., 
quando Roma estabeleceu contatos mais constantes com outros povos e encetou a conquista de territónios que a cercavam (mais como forma de proteger-se das agressóes externas do que para suprir anseios de domínio), ${ }^{79}$ influxos culturais estrangeiros adentraram pelas portas frontais da cidade, infirmando pouco a pouco os antigos mitos tribais e racionalizando a visão-de-mundo de seu povo. A erupção do desenvolvimento parece ter culminado no século IV a.C., quando tornaram-se fortes as influências helênicas e a conseguinte adoção do método dialético, baseado no estudo dos tupos (gêneros e espécies), via distinção e síntese, e dos princípios que os governam. ${ }^{\circ 0}$ Toda essa contingência evolutiva trouxe a Roma o cosmopolitismo do mundo antigo, fazendo com que a religião assumisse um papel secundário e que em seu lugar exsurgissem institutos que se justificavam não mais pela sacralidade, mas por encontrarem sua origem e seu fim na soberania do populus Romanus. ${ }^{81}$

Desse entremeio evolutivo, pode-se destacar alguns institutos jurídicos que especialmente interessam a este trabalho, e que também sofreram e sentiram em sua essência os efeitos da secularização operada em Roma. Despidos de suas vestes sacrais, alguns deles se extinguiram, outros se adaptaram, e outros, ainda, lograram ser mantidos praticamente

\footnotetext{
${ }^{79}$ Basta lembrar, como faz André Piganiol, que Roma iniciou protegendo-se de peque nos povos das cercanias (como os montanheses), para depois se atirar em combates contra civilizaçoes maiores (e.g. a Etrúria), sempre saindo-se vitoriosa anexando os territorios de sev entomo (PIGANIOL André, Histoire de Rome, cit, p. 50-51). Sobre as conquistas de maior expressão nos últimos séculos da República, veja-se ROSTOVTZEFF Mijail Historia social y económica del Imperio Romano (trad. Luis López-Ballesteros) Madrid: Espasa Calpe, 1998, t. 1, p. 31-101.

- As consideracoóes podem ser achadas en obra de Fritz Schulz, que ainda acrescenta ter sido a dialética o principal vetor de transfornaçâo da jurisprudência romana em ciência sistematica (SCHULZ, Fritz, History of roman legal science, cit, p. 6268).

:3 Como bem leciona Fergus Millar, ressalta aqui o poder crescente $\epsilon$ influente das assemblếas populares durante o periodo republicano (aprovação de leis, eleição de magistrados e judicatura nas comítia centuriata e comitia tributa), em eqüipotência aos líderes e ao Senado, circunstancia que acabou permitindo que Roma tivesse nuito dos elementos democráticos apresentados pela Atenas clássica (MILLAR, Fergus. The political character of the Classical Roman Republic 200-151 B.C. The Joumal of Roman Studies, 1984 v. 74, p. 2).
} 
nos mesmos trajes que o arcaísmo lhes envolvia, conforme "estivessem ou não enroscados à religião. E nesse sentido, já que elementos vinculados à lapidação da condemnatio formular, proceder-se-á à análise do destino dado à damnatio arcaica, das novéis ações da léi e do primeiro uso de sentenças cum damnatio.

Na época arcaica da histónia romana, a damnatio representava a 'garantia por submissão' aos deuses e aó credor de que certas promessas proferidas solenemente (via nuncupatio) seriam cumpridas, sob pena de coaçâo particular do credor (manus iniectio). Como se viu anteriormente, a publicidade das promessas e da garantia à sua realização (damnatio) era avalizada pela solenidade do ato e pela presença de testemunhas, de maneira a submeter o devedor à efetivação do que prometera ou à coerção religiosa e creditória exercida pelos beneficiários da declaração em caso de não cumprimento.

Essa concepção de damnatio como garantia e submissão coaduna perfeitamente às observações de alguns estudiosos que se detiveram em investigar as origens da obligatio romana. Na época arcaica, segundo eles, uma outra espécie de vínculo conectava os sujeitos e se caracterizava principalmente pela religiosidade e pela sujeição pessoal do devedor ao credor. Essa 'obrigação primitiva' (se assim possa ser dito) expressava unicamente a idéla de afetaçáo de pessoas como garantia ao cumprimento de uma prestação; ${ }^{82}$ ela se restringia, portanto, a garantir o cumprimento do que fora prometido. Como bem resume Giovanni Pugliese, tratava-se de vínculos conectados imediatamente a um 'resultado': permaneciam indefinidamente se esse 'resultado' não se verificasse, e se dissolviam, com a conseqüente liberação

\footnotetext{
${ }^{8}$ BARREIRO, Alejandrino Fernândez. Las fuentes de las obligaciones en relación con el sistema de acciones en derecho clásico. In: Derecho romano de obligaciones: homenaje al profesor José Luis Murga Gener. Madrid: Centro de Estudios Ramón Areces, 1994, p. 29.
} 
do sujeito passivo, se o 'resultado' se desdobrasse ${ }^{83}$ Eram relações com eficácia diretamente coercível sobre a pessoa do submetido, e por isso podiam dar ensejo imediato à manus iniectio ${ }^{84}$ Falar de damnatio, assim, é o mesmo que falar dessa primitiva obrigaçăo, caracterizada pela garantia ao cumprimento de promessas via submissão do próprio promitente.

É nítido que a damnatio tirava sua razäo de ser da nuncupatio: ela existia para garantir que as promessas proferidas solenernente seriam cumpridas. $O$ passar do tempo, porém, fez com que a nuncupatio se esvaziasse de sentido, pois a religiosidade romana que a imantava pereceu diante dos contatos de Roma com outras culturas, com o crescimento da cidade e com o florescimento de novas percepçōes da realidade. Esvaziada a nuncupatio, esvaziou-se a damnatio. Cedeu pouco a pouco à noção de obrigação como "vínculo ideal", a significar que o obligatus, para dela se libertar e não ser submetido à servidão corporal, devia proceder simplesmente à prestação do devido; ${ }^{85}$ a garantia deixava de ser o centro do vínculo interpartes. Como bem resume Arnaldo Biscardi, a obrigação não mais era uma ou outra das figuras de sujeição materialística do indivíduo em garantia de um comportamento devido, sujeita à discricionariedade do credor; ela passava a ser, ao contrário, um vinculum iuris, ou seja, uma relação jurídica meramente ideal. ${ }^{86}$

\footnotetext{
83 PUGLIESE, Glovanni Istituzioni di dintto romano, cit, p. I40.

24 BARREIRO, Alejandrino Femández, Las fuentes de las obligaciones en relación con el sistema de acciones en derecho clásico, cit. p. 30.

${ }_{85}$ Giovanni Puglese oferece passagem pertinente sobne $\mathrm{o}$ ponto, ao ensinar que 0 obligatus, "per liberarsi dal vincolo ideale e non vederlo convertirsi in asservimento corporale, "aveva la necessitä", non solo sil piano psicologico, ma anche su quello giuridico, di procurare la "prestazione" al "creditore". E "avere la necessità" aveva cominciato a essere tecnicamente indicato come oportere" (PUGLIESE, Giovanni, Istituzioni di dirito romano, cit, p. 141).

${ }^{86}$ BISCARDI, Analdo, La genesi del concetto classico di "obligatio". In: BISCARDI, Amaldo et alii. Derecho romano de obligdciones: homenaje al profesor losé Murga Gener. Madidi Centro de Estudios Ramôn Areces, 1994, p. 25.
} 
A iniciar pelas primeiras aparições de sponsio na Lei das XII Tábuas, o golpe fatal à predominância da garantia (e, por conseguinte, do reinado da damnatio) adveio com a lex Poetelia Papyria, em 326 a.C., fazendo prevalecer o debitum como essencial ao vínculo obrigacional e enxergando as garantias pessoais e reais como mero reforço da obrigaçāo. Diz-se que esse diploma representa "il colpo di grazia" da primitiva damnatio, ao passo que foi o prelúdio da posterior jurisprudência republicana e clássica no que tange à nova construção dogmática das relaçōes obrigacionais como tais. ${ }^{87} \mathrm{~A}$ damnatio cedia espaço mais e mais à obligatio. ${ }^{88}$

Não se sabe com plena certeza de que maneira a damnatio foi incorporada ao processo civil de modo a ensejar o posterior surgimento de sentenças cum damnatio e depois de condemnatio. O estudo da evolução do processo, contudo, oferece algumas pistas desse desenvolvimento, mormente por ser ele instrumento da realização concreta do justo abstrato e por isso em intenso câmbio. ${ }^{89}$

A presença de sentenças condenatórias na época arcaica - tal qual lapidadas no período formular - era incerta $e$ até mesmo improvável ${ }^{90}$ Elas só passaram a existir com a laicização do direito e coincidem exatamente à mutação

\footnotetext{
${ }^{8}$ BISCARDI, Arnaldo, La genesi del concetto classico di "obligatio", cit, p, 26.

8s Prova do que se diz é a própria abolição da manus iniectio ex damnatio, também por obra da lex Poetelia Papyria. Esse diploma legal - no mesmo contexto de introduçầo da obligatio - extirpou do processo civil a execuçăo pessoal, proibiu a escravidão, o flagelo corporal e a morte como decorrếncia de dívidas, e eliminou, assim, a possibilidade de execução ex damnatio, exigindo cognição judicial anterior para que a manus iniectio pudesse ser processada.

${ }^{39}$ Como afirma Abel $H_{*} \mathrm{~J}$. Greenidge, "procedure is always a symbolic manifestation of right" direito material e processo evoluem em ritmos distintos, de modo que o desenvolvimento do processo, por sua natureza instrumental, é o indício mais aparente do desenvolvimento do direito material (GREENIDGE Abel $\mathrm{H}$. J., The legal procedure of Cicero's time, cit., p. $3-5$ ).

"Diz Pugliese sobre o ponto: "nel processo per formulas la condemnatio del convenuto soccombente era normale; nelle legis actiones invece l'esistenza di una condemnatio non è precisamente attestata equindi e incerto se essa trovasse luogo in tutte le legis actiones contenziose o solo in alcune o solo a partire da una certa epoca" (PUGL.IESE, Giovanni, Il processo civile romano: le legis actiones, cit., p. 25, nota 31).
} 
do termo damnatio para condemnatio - prova, aliás, de que as palavras não sofrem modificações arbitrárias, mas acompanham o caminhar evolutivo das sociedades, e, por estarem imersas no todo cultural, experimentam mudanças paralelas, relacionadas e concomitantes às mutaçōes gerais. $O$ juízo das legis actiones resultava da legis actio sacramento, e consistia en decisão de um julgador inspirado por deuses que dizia se certa conduta estava ou não em conformidade ao direito reconhecido da época. Seu escopo năo era o adimplemento de deveres descumpridos, e sim a punição dos sujeitos que houvessem jurado em falsidade perante as deidades citadinas. ${ }^{9 !}$. Nos primeiros tempos, as partes respondiam com seu próprio corpo depois de ofertado juramento (per Iovem lapidem), e o sucumbente tornava-se homo sacer, sujeito ą sacrifício (sacer facio) para apaziguamento da ira divina. ${ }^{92}$ Seguindo a dinâmica evolutiva do iudicium, em pouco tempo (ainda na época da Monarquia), a garantia pessoal foi substituída pelo depósito expiatório (piaculum) de animais e depois pelo cobre, para, nos tempos decemvirais - com o assentamento do sistema capitalista romano e com o aparecimento das moedas (leis do século $V$ a.C.) -, ter-se de depositar quantia pecuniária. No período helếnico, o piaculum transformou-se em mera poena, o que demonstra, de certa forma, a decadência do sacramentum e de todo o universo de ações da lei frente à laicização das instituições.

É que as conquistas bélicas, o crescimento de Roma e o corte entre relígiấo e direito surtiram efeitos imediatos também na realidade das legis actiones, de maneira a minorar paulatinamente a relevância da legis actio sacramento $e$ oportunizar o nascimento de novos instrumentos processuais, bem melhor adequados aos novos tempos. Nesse sentido,

\footnotetext{
91. Indica Albanese que "un tal meccanismo rinvia ad una fase stonica nella quale la soluzione delle liti non si cercava attraverso criteri di indagine razionale e tecnicogiuridica, bensì attraverso mezzi volti a stabilire la confomità, o non conformità, alla volonta divina, d'una affermazione controversa" (ALBANESE, Betnardo, Il processo privato romano delle legis actiones, cit, p. 11 ).

${ }^{2}$ MEIRA, Silvio A. B., O homo sacer no antigo direito romano, cit., p. 9496.
} 
a época das XII Tábuas, na senda da introdução da moeda (nota 31), gerou o novel expediente do arbitrum liti ciestimandae, que consistia na indicação de um arbiter (no sentido de 'perito') e na transformação de uma res ou de um facere em pecúnia. Originariamente, o procedimento era externo ao sacramentum e à manus iniectio, mas servia de ponte para que a execução pudesse ser processada. A aestimatio era contratada pelo litigante vencedor, que, sob a obrigação de executar por quantia certa, tinha de transformar a "coisa" ou o "fazer" em dinheiro.

Aos poucos, essa e outras circunstâncias foram internalizando a aestimatio e determinaram o surgimento de uma nova ação da lei: a legis actio per iudicis arbitrive postulationem, criada por uma das leges Licinniae Sextae (século III a.C.), tendo em tempos iniciais a participação de um arbiter e posteriormente de um iudex. Diz-se que essa legis actio é amostra exemplar da dessacralização que a época portava ao direito romano, sobretudo porque foi a pioneira em introduzir a importante figura do iudex, na senda da recente criação do magistrado pretório (367 a.C.) e da abertura das fórmulas processuais ao estudo de jurisconsultos profanos (D. 1.2.2.7). Ao contrário da legis actio sacramento, a legis actio per iudicis arbitrive postulationem, além de utilizar-se do iudex, estava desprovida de quaisquer valorações sacrais, não obstante ainda perdurar a formalidade de pronunciaremse palavras solenes (certa verba) à sua admissibilidade. O sacramentum, por seu turno, mais e mais diminuía de importância, restando relegado a simples pena patrimonial, como já se viu anteriormente.

O juízo que essa nova ação da lei engendrava era absolutamente direto: pronunciava-se a existência ou a inexístência de uma obrigação violada, e de já lançava-se mão, pela primeira vez na história processual romana, de uma legítima condemnatio pecuniária. ${ }^{93} \mathrm{Se}$, de fato, a condenação como

93 Complementa bem Gioffedi: "erede dell'arbitium inteso alla valutazione della
pretesa, essa non si chiude con una pronuncia di valore puramente fomale, come it 
sentença era conseqüência lógica do exercício dos poderes decisórios outorgados ao iudex e por isso pressupunha que seu ato final estivesse revestido de império e autoridade, tal só poderia ser possivel em tempos que estivessem destituídos das permeaçôes religiosas e que fornecessem uma noção mínima de Estado, de maneira que um juízo direto e imperativo fosse de possível exaração. A legis actio per iudicis arbitrive postulationem parece ter oferecido de forma pioneira todas as condições para que uma sentença da estirpe pudesse ser proferida.

Resuma-se o que até aqui foi dito. $\mathrm{O}$ desenvolvimento de Roma, a partir do século V a.C., surtiu efeitos tanto na seara material quanto na seara processual do direito. A influência da religião nas instituições não era mais a mesma, e a noção de populus Romanus fortificou-se pouco a pouco de modo a ocupar as lacunas que a secularização deixava. Especialmente no que interessa, e como decorrência dessa evoluçäo cultural, o plano material do direito observou a paulatina substituição da idéia de 'obrigação como garantia' (damnatio) pela idéia de 'obrigação como vínculo ideal' (obligatio), de forma a fazer prevalecer o liame interpartes e tornar acessória a asseguraçăo de sua regular mantença.

Por sua natureza instrumental, o processo teve de acompanhar esse desenvolvimento jurídico-material. A antiga legis actio sacramento, por mais que tivesse sofrido modificações para se adaptar à nova contingência, não estava mais dando a resposta apropriada à realização dessas novéis obrigaçōes descumpridas. E não era de se esperar algo diferente: sua formatação era adequada aos vínculos com índole religiosa, em que o centro era a garantia, e não o débito. Daí que se explica o surgimento da legis actio per iudicis arbitrive postulationem, primeira ação da lei a patrocinar de forma mais completa a realização desses novos liames, a adiantar a

sacramenum iudicare, ma con la condemnatio pecuniaria, che a quelia pretesa dà direta soddisfazione: il giurato non soltanto iudicat, ma, con ciò stesso, condemnat" (GIOFFREDI, Carlo, Dintto e processo nelle antiche forme romane, cit. p. 168) 
própria formação do processo formular dos tempos clássicos. Não é à toa que a lex Poetelia Papyria, por consagrar a noção de obligatio e excluir a escravidão por dívidas, aboliu em absoluto a execução ex damnatio, seja porque o sumiço da nuncupatio não lhe dava mais razão de existência, seja porque a 'obrigação como garantia' cedia espaço à 'obrigação como vínculo ideal', e daí, por já não existir a força da garantia e a manus iniectio eminentemente particular, impunha a necessidade natural de proceder-se a uma cognição judicial prévia que desse azo ao conhecimento da obrigação e de seu descumprimento.

A universalização da necessidade de cognição prévia deu-se basicamente pelo perecimento da 'obrigação como garantia': a damnatio - que era uma de suas espécies e que ensejava, particularmente, uma manus iniectio direta, sem iudicium anterior - cedeu lugar à noção de 'obrigação como vínculo ideal', e seu poderio de submeter antecipadamente o devedor ao cumprimento de suas promessas assim desapareceu da praxe jurídico-material. No mesmo passo, a declaração do juiz passou a subsstituir a certeza religiosa fornecida pela nuncupatio, e a execução não podia mais ser realizada privadamente pelo credor, mas tão-somente sob a condução estrita e atenta do magistrado pretório. Todos esses elementos explicam, de alguma maneira, por que a damnatio deixou de existir, ao passo que fornecem indícios de como ela teria sido absorvida pelo processo e mais tarde se desenvolvido em sentenças de condemnatio.

Mas não há como saber com absoluta certeza de que maneira a damnatio tornou-se condemnatio. Na linha recémesboçada, cabe suscitar uma hipótese prática: que os julgadores romanos desenvolveram o costume de expressar a força de submissão que suas sentenças possuíam por meio do vocábulo damnatio; seriam, assim, sentenças cum damnatio, com submissão do réu ao populus Romanus ${ }^{94}$ Veja-se bem que o

${ }^{94}$ Como ja mencionado em linhas anteriores, a noção de populus Romanus de alguma forma substituiu o papel da religião nas instítuiçỏes de Roma, com impor tantes desdobramentos no âmbito do direito. 
uso da palavra não sofreu essencial modificação: ela continuou representando a idéia de submissăo do devedor ao cumprimento do prometido, e prosseguiu sendo proferida solenemente, mas agora pelo iudex e perante as partes eventuais terceiros que assistissem ao julgamento. Ao revés de submeter o devedor à religiăo e aos castigos sacrais pelo inadimplemento, a presença de uma damnatio na sentença (ou de uma sentença cum damnatio) o submetia ao populus Romanus por conseqüência da determinação judicial se descumprisse a sentença, estaria em desrespeito à soberania do povo de Roma, mormente pela dose de imperium que vinha repassada ao julgador através da fórmula.

A conclusâo aportada é coincidente a certas observaçōes de Carlo Gioffredi, que assim enxerga a condemnatio: "se trata antes de 'responsabilidade', do vínculo que nasce da litis contestatio, o qual porém não se concretiza numa obligatio: com a litis contestatio o réu não se empenha a um comportamento qualquer, mas este nasce, ao revés, de uma sanção social". ${ }^{95}$ Essa interação entre condemnatio e litis contestatio restará melhor analisada no capítulo seguinte, quando o objetivo precípuo será analisar ambos os institutos sob os entendimentos bosquejados até agora.

Por ora, resuma-se que a condemnatio sentencial submetia o réu ao cumprimento da determinação do iudex, detectada que estava a correspondência entre intentio formular e fatos de maneira a revelar que uma obrigação concreta fora desrespeitada. Por outro lado, ela servia de garantia ao crédito do autor, pois, de alguma maneira, o justo concreto seria preservado: ou pelo cumprimento voluntário da sentença, ou pela execução, se passados trinta dias. A submişão aqui mencionada, contudo - por força da humanitas, representada com força máxima na lex Poetelia Papyria -, năo dizia com o corpo do devedor mas com seu labor e mais normalmente com seus bens.

${ }_{55}$ GIOFFREDİ, Carlo, Dinito e processo nelle antiche forme giuridiche romane, cit, p. 159. 


\section{Condemnatio e Litis Contestatio}

A condemnatio formular foi fruto de uma evolução paulatina da damnatio arcaica, de maneira que alguns de seus aspec-tos originais se mantiveram e outros se adaptaram e se moldaram com o passar dos séculos e com o desenvolvimento da civilização romana $\mathrm{E}$ o que se viu até agora, sobretudo para aquilo que contribui à análise do aspecto interno da condenação do processo per formulas. Tomandose por pressuposto as conclusốes dos pontos anteriores, algo mais pode ser dito sobre a feição da condemnatio, e isso a partir do estudo de sua relação com a litis contestatio, conforme larga interpretação da romanística, aínda que ao fim e ao cabo vá se discordar do posicionamento adotado pela maioria.

Os estudiosos costumam extrair das Institutiones de Gaio a índole obrigacional da condemnatio, na qual ela recebe menção na condição de relacionada à solenidade da litis contestatio (III, 180): Tollitur adhuc obligatio litis contestatione, si modo legitimo iudicio fuerit actum. Nam tunc obligatio quidem principalis dissolvitur, incipit aiutem teneri réus litis contestatione; sed si condemnatus sit, sublata litis contestatione incipit ex causa iudicat teneri. Et hoc est quod apud veteres scriptum est, ante litem contestatam dare debitore oportere, post litem contestatam condemnari oportere, post condemnationem iudicatum facere oportere ("a extinção de uma obrigação é também efetuada pela litis contestatio, ao menos quando estatuído um iudicium legitimum. Entăo, a obrigaçấo original é dissolvida, e uma nova obrigaçâo é imposta ao réu, por causa da litis contestatio. Mas se ele é condenado, a obrigação exsurgente da litis contestatio é desconsiderada, e uma nova obrigação surge do julgamento. Como diziam os antigos juristas, antes da contestação da lide o devedor deve dar, depois da contestação da lide deve ser condenado, e depois da condenação deve cumprir o julgado"). 
Antes que se examine a relaçäo havida entre os institutos, há que se dar breves pinceladas sobre o conceito de litis contestatio. A doutrina mais tradicional, com assoreamento básico nas obras de Friedrich Keller e Moriz Wlassak, enxergava a como espécie de contrato, firmado por autor e réu, e de necessária celebraçáo para que o processo apud iudicem pudesse ser instaurado. Como bem resume Giovanni Pugliese - um aderente da tese clássica - a litis contestatio resultava de um acordo entre as partes, que consistia na proposta da fórmula por parte do autor e na sua aceitação por parte do réu. ${ }^{96}$ Segundo ele, o instituto estava imantado de natureza contratual privatística por conta de trés fatores: seu caráter negocial, a natureza arbitral do iudex e a feição privada de alguns outros atos que a ele sucediam. ${ }^{97}$

Esse posicionamento, porém, foi também rechaçado ao longo do últumo século. Uma das vozes mais autorizadas a lhe fazerem oposição saiu de Fritz Schulz, ao apontar ser equivocado raciocinar o processo e o direito romano de acordo com institutos hodiernos (id est ver a litis contestatio como se um contractus fosse). Também é erro imantar o iudex de um caráter arbitral que ele nâo possuía. Segundo Schulz, "o iudex pode ser equiparado a um árbitro, mas a um árbitro especial,

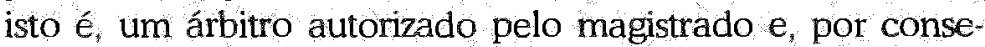
guinte, um delegado deste".99 Para complemento, basta lembrar que os iudices romanos eram prováveis componentes

\footnotetext{
96 PUGLIESE, Giovann. Processo privato e processo pubblico contributo allindividuazione dei loro caratteri nella storia del diritto romano, Rivista di diritto processuale. Padova: Milano, 1948 , v. 3, P. 67.

7) Idem, P. 68-70.

"La teoria de Wlassak es sostenida con argumentos endebles, con interpretaciones fallas de crítica y con deducciones inconectas" (SCHULZ, Friť, Derecho romano clásico, cit, p. 15 ).

9CHULZ, Frtz, Derecho romano clásico, cit, p. 15-16. A funça judicativa era um múnus püblico: por ser imprescindível à cogniçầo e â solução da demanda, nấo importava a individualidade da pessoa investida, mas tão-somente que fosse capaz de resolver da methor maneira o litugo, e tanto era assim que o pretor podia substituir o titular quantas vezes fossem necessaras, até que achasse um que exercesse as funçoes com 0 apuro exigido.
} 
do conselho do rei e, como continuação histórica, do próprio Senado de Roma.

Quanto aos outros dois fatores que Pugliese aponta como sendo evidências da natureza contratual-privatística da litis contestatio (o caráter negocial e a feição privada de atos sucessivos), algo mais pode ser dito. É certo que o procedimento apud iudicem só podia ser instaurado se ambas as partes estivessem presentes, mas isso não quer dizer que inexistissem maneiras de fazer com que a marcha processual prosseguisse. $O$ indefensus das actiones in personam (aquele que se negava a concluir a litis contestatio) podia ser conduzido à força (ductio) à casa do autor para daí decidir se aceitava a fómula ou se trabalhava para pagar a dívida quantificada no decreto do magistrado. A partir do século II a.C, a ductio foi substituída pela missio in bona; atribuindo-se a posse dos bens do indefensus ao autor e procedendo-se via imediata execução (actio iudicati) ${ }^{100}$ Noutras palavras, aquele que nầo aderia à fórmula e não participava da litis contestatio estava admitindo que as alegaçôes do autor eram verdadeiras, fato que dispensava a instauração do procedimento apud iuaicem e ensejava a execução. Não se pode falar, portanto, que a litis contestatio era um contrato, visto que a não aderência do requerido à fómula traża sançōes: o reconhecimento das alegações autorais, a supressão do procedimento cognitónio e a îmediata execução via actio iudicati. Ademais, não é correto imputar como inteiramente privadas as atuaçôes que sucediam à litis contestatio. No período formular, toda conduta das partes era regulamentada pela autoridade investida de imperium, através de leis ou de ordens suas.

Na verdade, a litis contestatio pouco ou nada possuía de contratual. Era apenas um momento de transição do procedimento in iure ao procedimento apud iudicem. ${ }^{101}$ Certamente

\footnotetext{
10 CANNATA, Carlo Augusto, Profilo istituzionale del processo privato romano: il processo formulare; cit., p. 170-175. Cf, tamben Gaio, Institutiones, III, 79.

ibr SCHULZ, Fritz, Derecho romano clásico, cit., p. 14
} 
abarcava desafios mútuos e assinalava que ambos estavam dispostos a litigar; "mas apenas em sentido impróprio se poderia dizer que ambos estavam 'de acordo' sobre a constituiçầo da lide; seu agir era um agir conservatónio, necessário para que fosse alcançado determinado fim: qual seja, o acertamento da demanda" ${ }^{02}$ Ainda que, no período arcaico, ela estivesse revestida de maior solenidade (já que então era ato de caráter tipicamente religioso, como demonstram certas passagens da obra De verborum significatione, escrita por Festo), a litis contestatio jamais teve feicóes contratuais. Era simplesmente a instauração do contraditório através da exposição das pretensões inconciliáveis (litis), com a invocação de testemunho (cum testatio) para incutir solenidade ao ato ${ }^{\text {i3 } 3}$ Secularizado o direito de Roma e maximizada a escritura, prescindivel tomou-se a presença das testemunhas, e a litis contestatio, então, perdurou como simples momento de transição entre procedimentos in iure e apud iudicem. ${ }^{104}$

A visão tradicional de ter-se a litis contestatio como um contrato também surtiu conseqüências no tangente ao estudo de seus efeitos; e aqui já se adentra no problema central deste capítulo: a análise das relações havidas com a condemnatio, tendo como ponto de partida o trecho gaiano citado linhas acima (Institutiones, III, 180). Dentre outros menos importantes, os principais efeitos da litis contestatio que a doutrina tradicional costuma apontar são três: o conservativo, o preclusivo e o extintivo-novatório. Os dois primeiros receberão abordagem resumida, pois é o terceiro que porta maior relevância e relação com a condemnatio.

Em primeiro plano, a litis contestatio assinalava que o conflito estava sendo colocado à apreciaçâa de um terceiro

\footnotetext{
10a GIOFFEDI, Carlo, Dirito e processo nelle antiche forme giuridiche romane, cit, p 153 .

10: A obra de Festo foi consultada da edição de BRUNS, Carolus Georgius. Fontes iuris romani aniqui. Tübingen: Lauppiana, 1871 , p. 180 .

ind GREENIDGE, Abel H. J., The legal procedure of Cicero's time, cit., p. 244
} 
imparcial a cuja decisão ambas as partes obrigatoriamente submeter-se-iam. Diz-se que tal efeito era 'conservativo', já que determinava a dedução da controvérsia ao juízo (rem in iudicium déducere), vetava quaisquer modificações que se quisesse efetuar na fórmula e fazia da discussão o objeto de uma decisão. ${ }^{105}$ Noutros termos, a litis contestatio assinalava que as partes aceitavam os termos da fórmula, a indicaçăo do juiz e a instauraçăo do procedimento conseguinte.

Estando a res in iudicium deducta, o objeto do litígio se tornava pendente de decisão do iudex, que era incorporado como parte na relação processual, de modo, inclusive, a fazer sua a lide (litem sua facere) nos casos de patente erro e/ou injustiça. Mas a influência de um terceiro imparcial só poderia se dar uma única vez sobre um mesmo conflito; a causa actionis, a partir da celebração da litis contestatio, nảo poderia ser repetida, e a esse efeito se atribuiu o nome de 'preclusivo'. E o que se conhece pelos brocardos latinos bis de eadem re agere non licet ou apenas ne bis in idem. Em suma, só se podia litigar uma única vez por uma mesma causa.

Enfim, o terceiro efeito que a doutrina tradicional costuma imputar à litis contestatio é o chamado 'extintivo-novatónio', e baseia-se principalmente na passagem de Gaio em que uma hipotética linha de obrigações está descrita. Era entendimento do jurista que a litiscontestaçăo tinha a capacidade de extinguir uma obligatio anterior e determinar a formação de uma nova (a condemnani oportere, i.e a obrigação de ser condenado), que só seria substituída com o advento da sentença, formadora de uma outra obrigação (a iudicatum facere oportere, i.e. o dever de cumprir o julgado). Relembre-se o trecho gaiano que melhor resume a idéia (Institutiones, III, 180): Et hoc est quod apud veteres scriptum est, ante litem contestatam dare debitore oportere, post litem contestatam condemnari

ios CANNATA, Carlo Augusto, Profilo istituzionale del processo privato romano: il processo formulare, cit., p. 165. 
oportere, post condemnationem iudicatum facere oportere ("como diziam os antigos juristas, antes da contestação da lide o devedor deve dar, depois da contestação da lide deve ser condenado, e depois da condenação deve cumprir o julgado"). Em suma, a linha obrigacional descrita por Gaio possui dois momentos extintivos-novatórios: (i) o momento em que a obrigaçâo anterior é extinta e substituída pelo dever de condenar; (ii) e o momento em que o dever de condenar extingue-se e dá lugar à sentença de condemnatio, gerando o conseguinte dever de que seja cumprida.

Como tantas vezes já foi dito, a doutrina tradicional firmou pilares nessa passagem para explicar boa parte do processo civil romano. O efeito extintivo-novatório da litis contestatio é largamente explicado através da seguinte linha: obligatio à actio à litis contestatio à condemnatio. Quem assim procede é um natural seguidor da noção de litiscontestação como contrato, já que, para que fosse operada uma novação de obrigações, fazia-se necessária a presença da figura privada de uma avença. Por isso que Friedrich Keller, um dos primeiros defensores desse entendimento, afirma, sem receios, em uma de suas obras: "o fundamento da actio era uma civilis obligatio". ${ }^{106}$ Desvelado também está o fundamento da idéia de actio, que, ao longo de todo o século XIX e em boa parte do século $\mathrm{XX}$, prendeu-se ao imanentismo de uma obrigação anterior, bem casada à definição que lhe deu Celso (D. 44.7.51) e que já recebeu tantas críticas da romanística mais desenvolvida ${ }^{107}$ Como se vế, essas noçốes

\footnotetext{
106. KELLER, Friedrich Ludwig. De la procedure civile et des actions chez les romains (rad. Charles Capmas). Paris: Emest Thorn, 1870, p. 265.

${ }_{107}$ Ad exemplum, vejamse as observaços de SCHULZ, Fritz, Principles of roman law, dit p. 4445. Na seara pátria, são admirấveis as críticas feitas por Pontes de Miranda, ainda que em breve trecho: "Os romanizantes, um pouco para salvar a materializaçao (ou, mais restitamente, a pivatizaçao celsiana), recorteram, ainda no seculo XX e no seculo XX, a vários "expedlentes". Com isso, insistiarn no êrro do proculeiano P. Juwêncio Celso Peripatético, portanto: a aplicação do direito, que seria forma, e a incidência, matéria, tomar-selam o mesmo, porque, no ser, o que importa é a forma; de modo que o direito privado e o processo eram um só direito" (PONTES DE MIRANDA, Francisco Cavalcanti. Tratado das açoes. 2. ed. Săo Paulo:
} 
de actio e de litis contestatio casam com perfeição, já que a condemnari oportere a a iudicium facere oportere nada mais eram do que um perdurar' da primitiva civilis obligatio dentro do processo, extinta por conta da instauração do litígio mas substituída por novas modalidades obrigacionais.

Emilio Betti talvez tenha sido um dos representantes mais eminentes desse entendimento, ainda que com algumas adaptaçōes. Segundo o jurista italiano, a litis contestatio criava no lugar da primitiva obligatio (deduzida em juízo) nảo uma nova e imediata obrigação de direito substancial, mas uma sujeição processual de caráter hipotético que futuramente poderia engendrar uma possível segunda obrigação de direito substancial, nascida da sentença condenatória. Noutras palavras, "uma responsabilidade inerente à obligatio principalis é absorvida na relação processual. Porém, é verdade que em tal relação vive, como consequência disso, o gérmen de uma obligatio de segundo grau. Mas tal gérmen chegará à maturação somente com a condenação". 108

Essa disseminada doutrina, que tinha a litis contestatio como se fosse um contrato e que lhe incutia efeitos extintivosnovatórios, pode ser refutada nos dias atuais com alguma tranqüilidade. Comece-se pela própria natureza do instituto, como já se viu em linhas anteriores. Ele nada tinha de contratual, mormente por faltar às partes a liberdade de não se submeterem a um processo caso assim não desejassem. Deixar de participar da litiscontestação (e tornar-se, assim, indefensus) implicava prescindir-se de um processo cognitónio e partir-se de imediato à execução pela actio iudicati. Noutras palavras, a liberdade esbarrava na existência de uma

Revista dos Tribunais, $1972, v, 1, p .91$ ) Basta lembrar que os romanos nä eram afeitos a definicoes, $o$ que de plano retira toda a importancia que, durante muíos anos, foi atribuida a definica de Celso (omnis definto in iure civili pericolosa est: ranm enim est, ut non subverti possel). Cf SCHULZ, Fritz. The invention of the Science of Law at Rome In: JAKOBS, Horst Heinrich. De similibus ad similia bei Bracton und Azo. Frankfurt Vitorio Klostermann Frankfurt am Main, 1996, p, 107. 168 BETT, Emilio. La struttura dell obbligazione romana e il problema della $\$$ ua genes. Milano: A Giuffre, 1955, p. I4. 
verdadeira sanção à nāo prática do ato. Ademais, comparar a litis contestatio a um contractus já é um equívoco de per si, como demonstrou Fritz Schulz: ${ }^{109}$ não se pode interpretar institutos de outrora sob o prisma do direito atual; a analogia aqui é sempre perniciosa.

A litiscontestação, ao revés, era mero momento de transição do procedimento in iure ao procedimento apud iudicem, e só esteve revestida de maior importância em tempos arcaicos porque consistia em atos de natureza religiosa (recordese: cum testatio, com a presença de testemunhas), portanto sem qualquer índole privatística-contratual. A razäo de sua celebraçăo - como se viu anteriormente - era instaurar o contraditório: por meio dela, expunham-se as teses conflitantes (litis) e preparava-se, dessa maneira, o procedimento guiado pelo iudex. Já se vê que não era sua finalidade extinguir ou criar quaisquer obrigações, mas apenas inaugurar o julgamento da causa.

Poder-se-ia cogitar que, independentemente de sua natureza, a litis contestatio tivesse o dom de gerar efeitos extintivos-novatórios; mas aí a hipótese esbarraria noutras considerações críticas. Apanhe-se, em primeiro lugar, a passagem de Gaio que tantas vezes já foi mencionada (Institutiones, III, 180). Do que está a tratạ o jurista nesse breve fragmento? De obrigaçōes. Aliás, boa parte do Livro III de sua obra tem como temática as obrigaçôes (ao lado das sucessões): obrigaçōes contratuais, fontes das obrigaçōes, extinção das obrigaçóes e obrigaçóes ex delicto. Săo temas de direito material; o processo só passa a ser abordado no Livro IV, e isso de maneira intencional (ou seja, o jurista deliberadamente procurou não misturar os dois campos). Mais que isso: ao mencionar a litis contestatio (III, 180), Gaio a observa como modo de extinção das obrigações ao laḍo de outras modalidades - como o simples pagamento (III, 168), a accepilatio (III. 169-172) e a novação (III, 176-179). Ou seja, ele não estava

SCHULZ, Fritz. Derecho romano clásico, cit. p. 15.

Cademos do PPG em Direito UFRGS, Porto Alegre, $4.6, n .7$ e 8, p. 223-291, 2007. 
descrevendo a natureza da litis contestatio ou mencionando que efeitos ela gerava, mas expondo uma das formas de extinção das obrigaçôes que ele considerava como existentes no direito de sua época.

Sua análise, portanto, é toda feita no plano do direito material, a partir da visão de quem é devedor: há uma obligatio que, com o processo, acaba substituída por uma condemnatio. Tanto que no começo, antes da contestação da lide, o devedor deve adimplir a obrigação (pois esta existe independentemente de reconhecimento judicial); depois da litis contestatio, ele está obrigado a acatar a futura sentença de condenação (ou seja, é certo que ele será condenado, pois é devedor); e, enfim, por força da condenação, o sujeito deverá prestar a obrigação que the incumbe. Vê-se bem que o devedor nunca deixa de ser devedor, mesmo com a instauração do processo. $\mathrm{E}$ isso porque, nessa parte de sua obra, Gaio não estava explicando como funcionava o processo, mas apenas descrevendo de que maneira uma obrigação se extinguia pelo cumprimento forçado via sentença de condenação. Para ele, o respeito à obrigaçã̃o via condemnatio sentencial era uma das modalidades de extinçäo das obrigaçōes.

Por năo estar tratando do processo ou da litis contestatio, chega a ser uma obviedade dizer que Gaio sequer cogitou a possibilidade de ter-se uma sentença de absolvição. Ele estava dissertando sobre as obrigaçôes e sobre as maneiras que levam-nas à extinção, e dentro desse prisma a condemnatio exsurgia como típica forma de cumprir-se forçadamente um dever assumido. Aqui parece repousar o erro capital da doutrina tradicional: não ter enxergado que o jurista não tratava da litiscontestação, da condenação ou dos efeitos que elas geravam, mas simplesmente abordava as maneiras pelas quais extinguiam-se as obligationes. É certo que houve incorreção na própria construçâo de Gaio quando atribuiu à litis contestatio o dom novatório, mal-interpretando a passagem dos veteres que ele mesmo citou. A lógica geral do processo civil romano, contudo, nấo permite que se propugne pela prevalência dos equívocos dessa passagem, mas pelo sucesso 
de simplesmente ter descrito a condemnatio como um dos veículos de cumprimento ex extinçâo obrigacional.

Mas há ainda outros argúmentos que demonstram fraqueza na interpretação tradicional, sobretudo quando se apanha para análise cada um dos dois momentos que a doutrina aponta como extintivos-novatórios.

O primeiro momento diz com a prática da litis contestatio. Como já se viu, a hermenêutica equivocada do trecho gaiano (III, 180) conduziu à crença de que o ato de litiscontestação extinguia a obligatio antes dela existente, substituindo-a pelo dever em obedecer-se à futura condemnatio. Nítido está que a visão é tipicamente ímanentista: ela parte não da perspectiva processual do ato (que demandaria enxergarem-se os momentos do processo a partir da perspectiva do pretor e do juiz), mas do prisma de quem é devedor, da visâo do sujeito que sabe estar obrigado a determinada prestação. Enfim, direito material e processo acabam misturados, e ao invés de analisar-se $o$ ato de litis contestatio, o raciocínio parte da certeza de que uma obrigação existe. A confusão entre os campos é típica da doutrina do século XIX, e já por isso se entende o porquê do surgimento, nessa época, de idéias imanentistas. ${ }^{110}$

O processo romano deve ser observado da perspectiva do pretor e do juiz, e, por isso, a partir da incerteza da qual a própria expressão formular si paret é representante. É exatamente dessa maneira que Gaio procede quando aborda o processo no Livro IV de suas Institutiones: sem qualquer referência à existência prévia de obrigaçōes. Tal seria não apenas misturar os planos e enxergar o processo sob o prisma do direito material, mas remontar à desgastada teoria civilista e acreditar que uma ação processual é desdobramento de uma obligatio descumprida.

\footnotetext{
$1 \%$ Dê-se apenas um destaque à tese de Friedrich Karl von Savigny, que de seus entendimentos fez derivat o que hoje se conhece por "teonia civilista da açäo", a pressupor a existência de um direito subjetivo e sua inflamação para que uma ação processual pudesse ser inaugurada (SAVIGNY, Friedrich Karl won. Sistema del dirito romano attuale (trad. Vitorio Scialoja). Torino: UTET, 1886, v. 5, 39204 e 205).
} 
O estudo das fases do processo romano e da atribuição de funções já revela que a seqüência obligatio $\rightarrow$ actio $\rightarrow$ litis contestatio $\rightarrow$ condemnatio é de todo equivocada. Quando ouvia as partes e as auxiliava na redação da fórmula, ao pretor não interessava se o autor tinha ou não razão naquilo que pronunciava. Não era sua preocupação - pois não era seu ofício - exarninar se intentio e fatos tinham correspondência e se, portanto, havia uma obrigação descumprida. Seu labor (o de redigir a fórmula e dar uma ação) era exercido independentemente da existência de uma obligatio. É bem isso que se viu no capítulo 3.1: que o pretor năo averiguava se o exposto pelo requerente correspondia à verdade, mas aceitava-o provisoriamente como verdadeiro e decidia se aos fatos expostos cabia um direito que se pudesse fazer valer pela via processual. ${ }^{11}$ Como se disse, ao magistrado pretório incumbia: (i) verificar se as pretensöes do autor eram tuteláveis (analisando se um juízo era necessário e harmônico ao direito reconhecido, sob pena de denegare actionem), (ii) auxiliar na redação da fórmula e (iii) autorizar a instauração do procedimento apud iudicem. Isso implica dizer que a actio não pressupunha uma obligatio para que fosse concedida pelo pretor, mas apenas a narrativa das partes. ${ }^{112}$

Era assim, aliás, que o direito material (o já denominado 'justo abstrato') penetrava e influenciava de maneira cabal o processo: por meio das alegaçōes de autor e réu. Era a partir delas que o pretor dizia o direito e auxiliava os envolvidos

\footnotetext{
11 Essas são palavras de KASER, Max, Derecho romano privado, cit., p. 355.

${ }_{152}$ Desde que entenda-se 'actio? como conduta, procedimento, ação genericamente dita, conforme razoável interpretação de Fritz Schulz (cf nota 51). Acredita-se aqui que os romanos do período fomular não imputaram à actio a importância de uma categoria jurílica a ser formulada ediscutida. Para eles; actio era simplesmente "agir" conduzir-se de determinada maneira?. Tanto que a palavia nunca vinha desacompanhada: para os romanos, actio nunca era apenas actio, mas actio para o exercício de deteminada conduta. Esa, portanto, proceder em sentido lato (seja material, seja processual) carente de complemento, e não uma categoria juridica. Essas observaçoes säo pertinentes para que näo se atribua a este trabalho o erro de observar a actio romana a partir da teoria abstrata da açäo. O trato que aqui se dă, conforme recém-vísto - e que acredita se tenha sido o uso romano da palavra -, é no sentido da nâo adoçäo de entendimentos modemos para a explicaçăo do processo romano.
} 
para que fosse redigida uma fórmula adequada à solução do caso, em que constasse abstratamente o modelo de justo (direito material) para servir de paradigma à verificaçẫo do liame existente entre as partes e ao eventual ajuste caso houvesse iniquaidade. ${ }^{13} \mathrm{E}$ aqui já se adentra também no oficio do iudex: exatamente o de detectar se correspondiam intentio e fatos, isto é, se realmente havia uma obrigaçăo descumprida que carecesse de reforço. Em caso positivo (si paret), uma condenação haveria de ser lapidada; em caso negativo (si non paret), uma absolutio era proferida $E$ isso que foi visto com amplitude no capítulo 3.2 e que aqui merece apenas referência.

Veja-se que isso exclui de plano a possibilidade de ver-se a litis contestatio como um ato que extinguia uma obrigação anterior. Tal seria admitir que uma actio é desdobramento de uma obligatio, e isso, como se vê, nầo coaduna à lógica geral do processo romano e sobretudo ao ofício do pretor e do juiz.

Ainda no primeiro momento extintivo-novatório; sequer é possivel sustentar que uma nova obrigação era gerada pela solenidade da litíscontestaçăo, e isso independentemente de aceitarem-se ou não as teses imanentistas ora criticadas. A conclusão do ato submetia as partes ao julgamento do iudex, mas de maneira alguma representava o surgimento de uma obligatio. Bem ao contrário, o novo vínculo não apenas ligava um sujeito ao outro, mas os submetia ao imperium do populus Romanus, outorgado ao praetor pelos cidadãos e repassado

\footnotetext{
is susto abstrato porque espelhado na fómula (ius dicere, iurisdictio, dizer o direito, dar a descriçáo abstrata, a partir das alegaçōes concretas do que senia uma relaçâo equilibrada e isonómica, descriçăo esta que servia de instrumento - por íso lus era visto como técnica - ao juiz para realizar o bom e o eqüitativo no caso ooncreto), e posteriormente nos editos e nas legislaçóes dos periodos mais avançados do direito romano (que decorreram, por lógica, da repetiçāo empreendida pelos pretores de um mesmo justo abstrato, de uma mesma tecnica para a resolução de casos similares). Sobre isso, vejam-se as interessantíssimas consideraçöes de GALLO, Filippo, Aspetti peculian e qualificanti della produzione del diritto nell esperienza romana. Rivista di dirtto romano, $v$ 4, 2004. Acessivel em: <http //wwwledonine it/rivistadiritoromano/>.
} 
ao îdex através da fórmula: Ademais, argumentar que a litis contestatio era "fonte de obrigaçōes" é posicionamento só harmônico à doutrina que enxerga o ato como se um contrato fosse. A análise do instituto como 'momento processual de transição' entre um e outro procedimentos extirpa a possibilidade de vế-lo como um instituidor de obligationes. Nada existia de extintivo e menos ainda de novatório na litis contestatio.

Ao segundo momento extintivo-novatório (id est à condenação) também é imputado o condão de eliminar e criar obrigações. De tudo que já se viu nos capítulos anteriores, contudo, não parece ter sido essa a causa e a função da sentença de condemnatio. Bem ao contrário, a sentença de per si (fosse ela condenatória, fosse absolutória) era um ato de imperium: sua força decorria da competência judicativa outorgada pela fórmula pretónia; era a culminação do cotejo entre intentio formular e fatos; e quando condenatória, consubstanciava-se não na geração de uma nova obligatio, mas no reforço de obrigações que já existiam antes do próprio processo, via submissão do condemnatus ao imperium do populus. Nos moldes de outrora (idos da damnatio), a condenação representava a idéia de submissão do devedor ao cumprimento do prometido, mas também à sentença que por sua própria natureza espelhava a vontade e o império do povo romano. Descumprida a decisão, desrespeitado estava o populus.

Portanto, sequer esse segundo momento do processo romano estava imantado de caráter extintivo-novatório. A condemnatio sentencial não tinha nem por causa nem por efeito a existência de obrigaçōes. Ao revés, o que lhe dava ensejo era o imperium magistratural e a lógica de correspondência entre intentio e fatos, e o que ela gerava não eram novas obligationes, mas a submissäo do condenado ao cumprimento de deveres descobertos como inadimplidos (por conta da instrução processual), com a garantia de que seu patrimônio responderia pelas dívidas caso o descumprimento perdurasse mesmo à ordem judicial. 


\section{Conclusão}

De tudo o que foil visto, pode-se sugerir que as origens da condenaçâo sentencial do processo civil romano repousam em duas circunstâncias básicas: na figura da damnatio arcaica e nas condiçóes históricas favoráveis que desenvolveram tanto a noção de obrigação quanto os instrumentos processuais utilizados para sua efetivaçâo. Conforme já visto nos capítulos deste trabalho, a algumas conclusóes logrou-se chegar.

1. A condemnatio tem como antecedente arcaico a pala vra damnatio, que aparecia na condiçáo de relacionada ao votum, aos legados per damnationem e sinendi modo, e ao nexum, e expressava basicamente a instituição de uma garantia para o cumprimento de certas promessas proferidas solenemente (nuncupatio), diante de testemunhas (testis). Imantada de índole religiosa, sua presença submetia o promitente às penas pelo descumprimento, que se resumiam, basicamente, em puniçôes religiosas e na servidão de seu próprio corpo ou de seu labor ao poderio do beneficiário (manus iniectio ex damnatio). A damnatio parece ter sido uma das modalidades antigas de obrigação, já que nesses idos, dada a permeação total da religião às instituiçốes romanas, o centro do vínculo era a garantia, e nảo o debitum (como mais tarde seria, com o surgimento da obligatio).

2. Pulando-se ao período formular do processo romano, a condemnatio aparecia como parte da fórmula e como sentença Como pars formulae, a condemnatio representava a outorga de imperium judicativo ao juiz, que tinha como origem o próprio populus Romanus e as atribuiçóes de que o pretor era investido. Sua função, aliâs, deve ser vista dentro do prisma evolutivo de pretor e fómula, que nasceram e pereceram unidos na história processual de Roma. Como sententia, a condemnatio pode ser vista sob seu aspecto externo e sob seu aspecto interno. No que tange ao primeiro, pode-se dizer que ela resultava do cotejo positivo entre intentio formular e fatos (via instrução processual), que revelava haver no caso concreto uma iniqüidade que dependia de ajuste. Com o 
tempo, passou a ser escrita e fundamentada, sobretudo por conta do perigo de litem suam facere, mas invariavelmente expressa em termos pecuniários.

3. No que tange ao aspecto interno da condemnatio, é possível afirmar que o desenvolvimento das instituições como um todo acabou por substituir paulatín a idéía de 'obrigação como garantia' (damnatio) pela idéia de obrigação como vínculo ideal' (obligatio), determinando, por outro lado, o desenvolvimento dos instrumentos processuais em diversos de seus princípios. Minorada a influência da religiāo, esvaziou-se a ratio da damnatio, e ela, de alguma forma (provavelmente por uma prática adotada pelos julgadores romanos), foi internalizada ao sentenciamento, fazendo perdurar, no entanto, a idéia de submissão do devedor ao cumprimento do prometido e boa parte da solenidade de que antes se revestia. Ao revés de submetê-lo à religiáo e aos castigos sacrais, a damnatio sentencial (ou a sentença de cum damnatio) o submetia ao populus Romanus (ao imperium) por conseqüência da determinaçâo judicial: caso descumprisse a sentença, a soberania do povo é que estava sendo desrespeitada.

4. Enfim, o aspecto interno da sentença de condemnatio ressalta ainda mais quando cotejada à litis contestatio e aos momentos extintivo-novatórios que a doutrina deduziu de um trecho de Gaio (Institutiones, III, 180). Se já a litiscontestação não possui como causa e como efeito a existência de obrigações menos ainda a condemnatio. Esta, como se viu, nâo era desdobramento de uma obligatio, mas da competência judícativa outorgada ao iudex e daquilo que era resultado do cotejo entre intentio formular e fatos; e por outro lado, náo se consubstanciava na formação de obrigaçōes, mas no reforço de deveres que existiam antes mesmo do processo, via submissâo do condenado ao imperium do Estado romano (melhor dizendo, do populus Romanus). ${ }^{114}$

\footnotetext{
114 Como antes ja fol dito, parafraseando se Marc Bloch, o passado $\epsilon$, por definiçằ, um dado imodificável; seu conhecimento, porém, é coisa que progride, e que
} 


\section{Referências}

ALBANESE, Bemardo. H processo privato romano delle legis actiones. Palermo: Palumbo, 1993.

BARREIRO, Alejandrino Fernández. Las fuentes de las obligaciones en relación con el sistema de acciones en derecho clásico. In: Derecho romano de obligaciones: homenaje al profesor José Luis Murga Gener. Madrid: Centro de Estudios Ramón Areces, 1994

BETTI, Emilio La struttura dellobbligazione romana $e$ il problema della sua genesi. Milano: A. Giuffrè, 1955

BIONDI Biondo. Corso di diritto romano. Diritto ereditario Milano A. Giuftre 1934.

Legato (diritto romano). Novissimo Digesto Italiano. Torino: Unione Típografico-Editrice Torinese, [s.d.], v. 9.

BISCARDI, Amaldo. La genesi del concetto classico di "obligatio" "In: BISCARDI, Arnaldo et alii Derecho romano de obligaciones: homenaje al profesor José Murga Gener Madrid: Centro de Estudios Ramón Areces, 1994.

BLOCH, Marc Apologie pour lhistoire ou métier d'histonen (Cahiers des Annales). 2. ed. Paris: Ammand Colin, 1952.

BOPP, Franz, Grammaire comparée des langues indo-européennes (trad. Michel Bréal). 2. ed: Paris: Imprimerie Impériale, 1866, t. I.

BRUNS, Carolus Georgius. Fontes iuris romani antiquil. Tübingen: Lauppiana, 1871 .

CANNATA, Carlo Augusto. Profilo istituzionale del processo civile romano: le legis actiones. Torino: Giappichelli, 1980.

Profilo istituzionale del processo civile romano: il processo formulare: Torino: Giappichelli, 1982.

CRIFO, Giuliano. Danno (storia). In Enciclopedia Giuridica Italiana. [s.1.]: A Giuffrè, 1962.

CRUZ, Juan Cruz. La historia como tradición. Anuario filosófico. Navarra: EUNSA, v. 13, n. 1, 1980.

incessantemente se transforma e se aperfeiçod (BLOCH, Marc: Apologie pour l'histoire ou metier d'historien, cit. p. 22). Sob esse pressuposto, sabe-se que muitos dos pontos deste trabalho estão crivados de diversas imperfeiçoes e lacunas que só com o tempo, com pesquisas mais aprofundadas e com as críticas que adviräo poderâo ser sanadas - $\mathrm{e}$ anda assim nấo em seu totum. Fica a esperança de que, mesmo no erro, sirva ele de impulso adicional à pesquisa e à discussão histónica.

Cademos do PPG em Direito UFRGS, Porto Alegre, v. 6, r. 7 e 8, p. 223-291, 2007. 
DEVOTO, Gacomo. Ricostruzione e storia di lingue. In: Scritti Minori. Firenze: Felice le Monnier, 1967, v. 1.

D'ORS, Álvaro. Derecho privado romano. 9. ed. Navarra: EUNSA, 1997.

ENGELMANN, Arthur et alii. History of continental civil procedure (trad. Robert Wyness Millar). Nova Iorque: Rothman Reprints e Augusts M. Kelley, 1969.

ERNOUT, A. Les éléments êtrusques du vocabulaire latine. Bulletin de la société de linguistique de Paris. Paris: Librarie Ancienne Honorê Champion, 1930, t. 30 .

ERNOUT, A.; MEILLET, A Dictionnaire etymologique de la langue latine; histoire des mots. 3. ed. Paris: C. Klincksieck, 1951.

FIRPO, Gulio. Votum. In: Novíssimo Digesto Italiano. Torino: Unione Tipografico - Editrice Torinese, [s.d.], v. 20.

GALLO, Filippo. Lofficium del pretore nella produzione e applicazione del diritto. Torino: P. Giappichelli, 1997.

Aspetti peculiari e qualificanti della produzione del diritto nell'esperienza romana. Rivista di dirito romano, v. 4, 2004. Acessivel em: $<$ hitp:/wwwledonline.it/rivistadirittoromano/ $>$.

GIOFFREDİ, Carlo. Dirito e processo nelle antiche forme romane. Roma: Apollinaris, 1955.

- Nexum. Nouíssimo Digesto Italiano: Torino: Unione Tipográfico Editrice Torinese, [s.d.], v. 11

GONZALES, Julian; CRAWFORD, Michael. H. The Lex Irnitana: a new copy of the Flavian Municipal Law. The Journal of Roman Studies, 1986, v. 76.

GREENIDGE, Abel H.J. The legal procedure of Cicero's time. Oxford: Clarendon Press, 1901

GUARINO, Antonio. La condanna nei limiti del possibile. 2. ed. Napoli: Jovene, 1978.

IMBERT, Jean. Fides et nexum. Studi in onore di Vicenzo Arangio-Ruiz. Napoli: Jovene, [s.d.], v. 1.

JHERING, Rudolf von. LEsprit du droit romain (trad. O. de Meulenaere). 3. ed. Paris: [s.n.], 1886-1888.

JOLOWICZ, H. F. Case law in roman Egypt. The journal of the Society of Public Teachers ofLaw. [s.l.]; [s.n.], 1937, n. 14.

JÖRS, Paul; KUNKEL, Wolfgang. Derecho privado romano (trad. L. Pietro Castro). Barcelona: Labor, 1965. 
KASER, Max Derecho romano privado (trad José Santa Cruz Teijeiro). 5. ed. Madrid: Réus, 1968.

KELLER, Fnedrich Ludwig. De la procédure civile et des actions chez les romains (trad. Charles Capmas). Paris: Emest Thorin, 1870.

LEVY-BRUHL, Henri. Prudent et préteur. Revue historique du droit français et étranger. Paris: Recueil Sirey, 1926, ano 5.

Le sacramentum in personam. In: Studi in onore di Vicenzo ArangioRuiz. Napoli: Jovene, [s.d.], v.2.

MAINE, Henry Sumner Ancient low. Londres. Aldine Press - Letchworth Herts (Everyman's Library), 1965.

MANTOVANI, Dario. Le formule del processo privato romano. 2. ed. Padova: CEDAM 1999.

MEIRA, Silvio A. B. O homo sacer no antigo direito romano. Romanitas: Revista de Cultura Romana (língua, instituiçōes e direito). Rio de Janeiro: Romanitas, 1959, ano 2, v. 2.

METZGER, Emest. A new outline of the roman civil trial Oxford: Clarendon Press, 1997

Interrupting proceedings in iure: vadimonium and intertium. Zeitschrift für Papyrologie und Epigraphik, n. ${ }^{\circ} 120,1998$.

Roman judges, case law, and principles of procedure. Law and history review (separata), 2004, n. $22 / 2$.

MILLAR, Fergus. The political character of the Classical Roman Republic 200 151 B.C. The Journal of Roman Studies, 1984, v. 74.

MOMMSEN, Theodore. Histoire de la monnaie romaine (trad. Duc de Blacas) Paris: [s.n.], [s.d.], t. 1.

NOAILLES, Pierre. Fas et ius: études de droit romain. Paris: Les Belles Lettres, 1948 .

. Du droit sacré au droit civil Paris: Recueil Sirey, 1949.

PIGANIDL, André Histoire de Rome. Paris: Presses Universitaires de France 1939.

PONTES DE MIRANDA, F. C. Garra mão e dedo. Campinas: Bookseller, 2002. Tratado das açōes. 2. ed. São Paulo: Revista dos Tribunais, 1972, v. 1. PUGLIESE, Giovanni. Istituzioni di diritto romano, 3. ed. Tonno: G. Giappichelli, 1991 .

Il processo civile romano: le legis actiones. Roma: Ricerche, 1961-62.

Cademos do PFG em Direito UFRGS, Porto Alegre, v. $6, n .7$ e 8, p. 223-291, 2007. 
Processo privato e processo pubblico: contributo all individuazione dei loro caratteri nella storia del dirittó romano. Rivista di diritto processuale. Padova: Milano, 1948, v. 3.

RICHARDSON, J.S. Imperium Romanum, empire and the language of power. The Journal of Roman Studies, 1991, v. 81.

ROMANO Angela. Condanna "in ipsam rem" e condanna pecuniaria nella storia del processo romano Labeo rasegna di diritto romano. [s.1.] [s.n.], 1989, n. 28 .

ROSTOVTZEFF, Mijail. Historia social y económica del Imperio Romano (trad. Luis López-Ballesteros). Madrid: Espasa Calpe, 1998 t 1 .

SARAIVA, F R dos Santos Novïssimo dicionánio latino português etimológico, prosódico, histórico, geográfico, mitológico, biográfico, etc. 11. ed. Rio de Janeiro - Belo Honzonte: Garnier, 2000.

SAUSSURE, Ferdinand de Cours de linguistique générale 2. ed. Paris: Payot 8 Cie., 1922.

SAVIGNY, Friedrich Karl von. De la vócación de nuestro siglo para lalegislación y la ciencia del derecho (trad. Adolfo G. Posada). Buenos Aires: Atalaya, 1946. UTET, 1886, v. 5.

Sistema del diritto romano attuale (trad. Vittorio Scialoja). Torino:

SCHULZ, Fritz. Principles of roman law (trad Marguerite Wolff). Oxford: Clarendon Press, 1956. Bosch, 1960 .

Derecho romano clásico (trad José Santa Cruz Teijeiro). Barcelona:

History of roman legal science. Oxford: Clarendon Press, 1967.

The invention of the Science of Law at Rome. In: JAKOBS, Horst Heinrich. De similibus ad similia bei Bracton und Azo. Frankfurt: Vittorio Klostermann Frankfurt am Main 1996.

SCIALOJA, Vittorio. Procedimiento civil romano: ejercicio y defensa de los derechos (trad. Santiago Santis Melendo e Marino Ayerra Redin). Buenos Aires: EJEA, 1954.

SENN, Félix. Nexum: contract de prêt du trés ancien droit romain. Nouvelle revue historique du droit français et étranger. Paris: Recueil Sirey, ano 29, 1905.

SERRAO, Feliciano La iurisdictio del pretore peregrino Milano: Giuffrè, 1954.

TALAMANCA, Mario et alii. Lineamenti di storia del diritto romano. 2. ed. Milano: Güffrè, 1989.

THOMAS, Paul. La nature de la damnatio. Revue historique de droit français et étranger. Paris: Recueil Sirey, série 4, ano 10, 1931. 
VILLAR, Alfonso Murillo. La motivación de sentencia en el proceso civil romano. Cuadernos de historia del derecho. Madrid: Complutense, 1995, n. ${ }^{\circ} 2$.

WEBER, Max. Historia económica general (trad. Manuel Sánchez Sarto). México: Fondo de Cultura Económica, 1997.

WHITMAN, James Q. The legacy of Roman Law in the German Romantic Era: historical vision and legal change. Princeton: Princeton University Press, 1990.

WORMS, René De la volonté unilatérale considérée comme source d'obligations en droit romain et en droit français. Paris: A. Girard; 1891. 
